\title{
Energy Use and Carbon Dioxide Emissions in the Steel Sector in Key Developing Countries
}

\author{
Lynn Price, Dian Phylipsen, Ernst Worrell
}

April 2001

\author{
Energy Analysis Department \\ Environmental Energy Technologies Division \\ Lawrence Berkeley National Laboratory \\ University of California \\ Berkeley, CA 94720
}

This work was supported by the Office of Atmospheric Programs, Office of Air and Radiation, U.S. Environmental Protection Agency through the U.S. Department of Energy under Contract No. DE-AC03-76SF00098. 



\title{
Energy Use and Carbon Dioxide Emissions in the Steel Sector in Key Developing Countries
}

\author{
Lynn Price, Dian Phylipsen, Ernst Worrell \\ Energy Analysis Department \\ Environmental Energy Technologies Division \\ Lawrence Berkeley National Laboratory
}

\begin{abstract}
Iron and steel production consumes enormous quantities of energy, especially in developing countries where outdated, inefficient technologies are still used to produce iron and steel. Carbon dioxide emissions from steel production, which range between 5 and $15 \%$ of total country emissions in key developing countries (Brazil, China, India, Mexico, and South Africa), will continue to grow as these countries develop and as demand for steel products such as construction materials, automobiles, and appliances increases. In this report, we describe the key steel production processes, discuss typical energy-intensity values for these processes, review historical trends in iron and steel production by process in five key developing countries, describe the steel industry in each of the five key developing countries, present international comparisons of energy use and carbon dioxide emissions among these countries, and provide our assessment of the technical potential to reduce these emissions based on best-practice benchmarking. Using a best practice benchmark, we find that significant savings, in the range of 33\% to $49 \%$ of total primary energy used to produce steel, are technically possible in these countries. Similarly, we find that the technical potential for reducing intensities of carbon dioxide emissions ranges between $26 \%$ and $49 \%$ of total carbon dioxide emissions from steel production in these countries.
\end{abstract}

\section{Introduction}

The industrial sector is the most important end-use sector in developing countries, and was responsible for 50\% of primary energy use and 53\% of associated carbon dioxide emissions in 1995 (see Figure 1) (Price et al., 1998). The industrial sector is extremely diverse, encompassing the extraction of natural resources, conversion into raw materials, and manufacture of finished products. Five energy-intensive industrial subsectors account for the bulk of industrial energy consumption and related carbon dioxide emissions (iron and steel, chemicals, petroleum refining, pulp and paper, and cement).

Iron and steel production consumes enormous quantities of energy, especially in developing countries where outdated, inefficient technologies are still used to produce iron and steel. Production of steel in developing countries has grown at an average annual rate of $6.6 \%$ in recent years (IISI, 1997) and is expected to continue to grow at similar levels due to the current low per capita steel consumption levels in these countries. In contrast to industrialized countries, where steel consumption averages over $425 \mathrm{~kg} / \mathrm{capita}$, key steel-producing developing countries have extremely low per capita consumption levels of $80 \mathrm{~kg} / \mathrm{capita}$ in 1995. Carbon dioxide emissions from steel production, which range between 5 and $15 \%$ of total country emissions in key developing countries (Brazil, China, India, Mexico, and South Africa), will continue to grow as these countries develop and demand for steel products such as construction materials, automobiles, and appliances increases.

In 1995, carbon dioxide emissions from steel production in Brazil, China, India, Mexico and South Africa combined were $117 \mathrm{MtC}$. If steel production had been at levels similar to those in industrialized countries (i.e., $425 \mathrm{~kg} / \mathrm{capita}$ ) in these five countries in 1995, the resulting carbon dioxide emissions would have been $875 \mathrm{MtC}$, more than sevenfold increase (IISI, 1996a; UN, 1996). Most of the increased emissions would have been in China and India, countries with high populations and low per capita consumption levels (see Figure 2).

In this report, we begin with an industry overview in Section II, in which we describe the key steel-production processes and discuss typical energy-intensity values for these processes. We discuss historical trends in iron and steel production by process in five key developing countries in Section III. This is followed by a description of the

\footnotetext{
${ }^{1}$ We define "key developing countries" as those developing countries within the group of top-20 steel producers in 1995 for which we had adequate data to perform the analyses in this report. Two other developing countries, South Korea and Turkey, were in the group of top-20 steel producers in 1995 but were not included in this analysis due to lack of data on energy consumption for steel production.
} 
steel industry in each of the five countries, including plant-specific production and process information in Section IV. Section V presents international comparisons of energy use and carbon dioxide emissions for the steel industry in the five key developing countries, including our assessment of the technical potential to reduce these emissions based on best-practice benchmarking. Section VI presents our conclusions.

Figure 1. Developing Country Carbon Dioxide Emissions

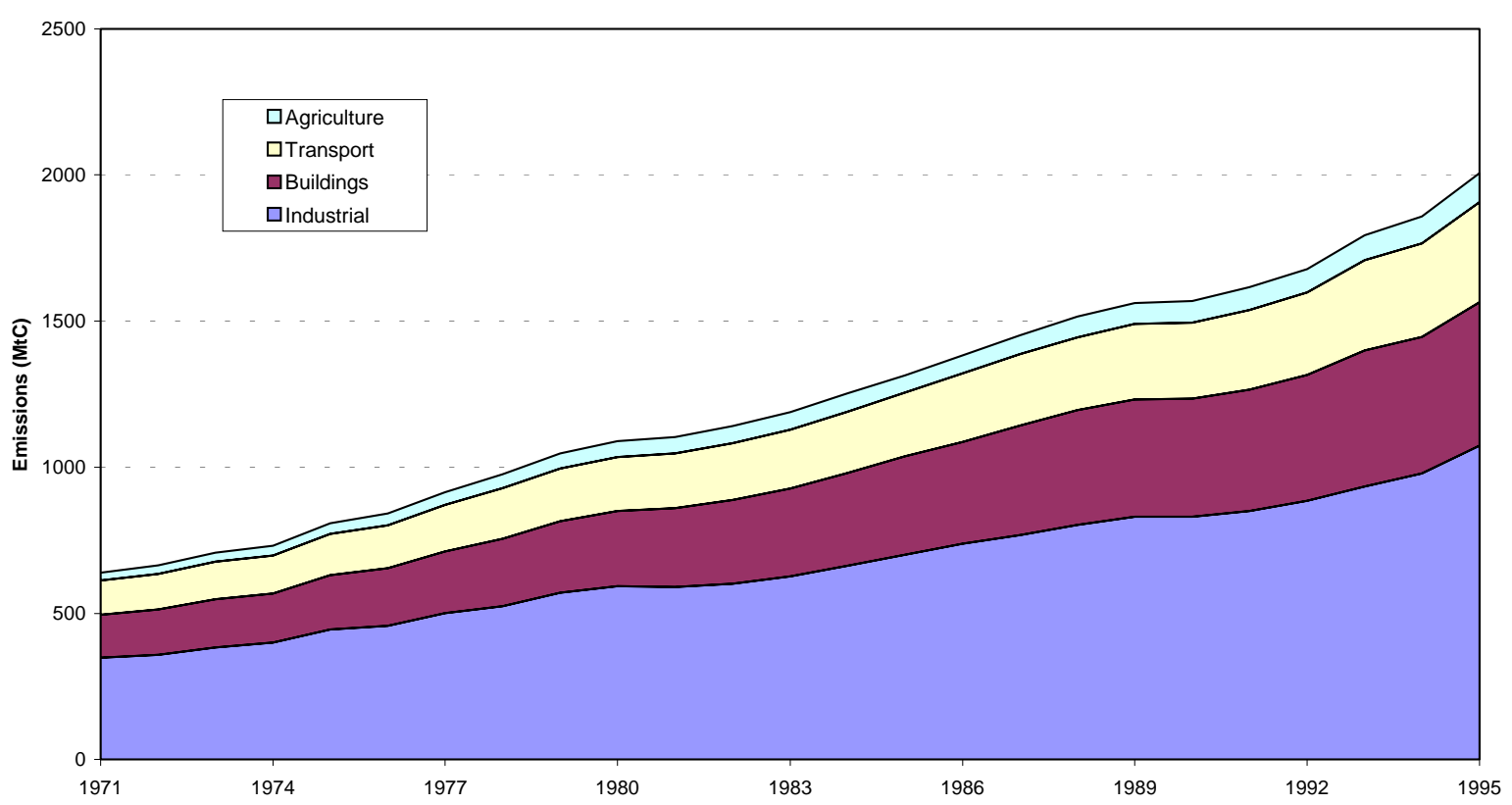

Figure 2. Carbon Dioxide Emissions from Steel Production based on Actual and Industrialized Country Average Per Capita Steel Consumption Levels

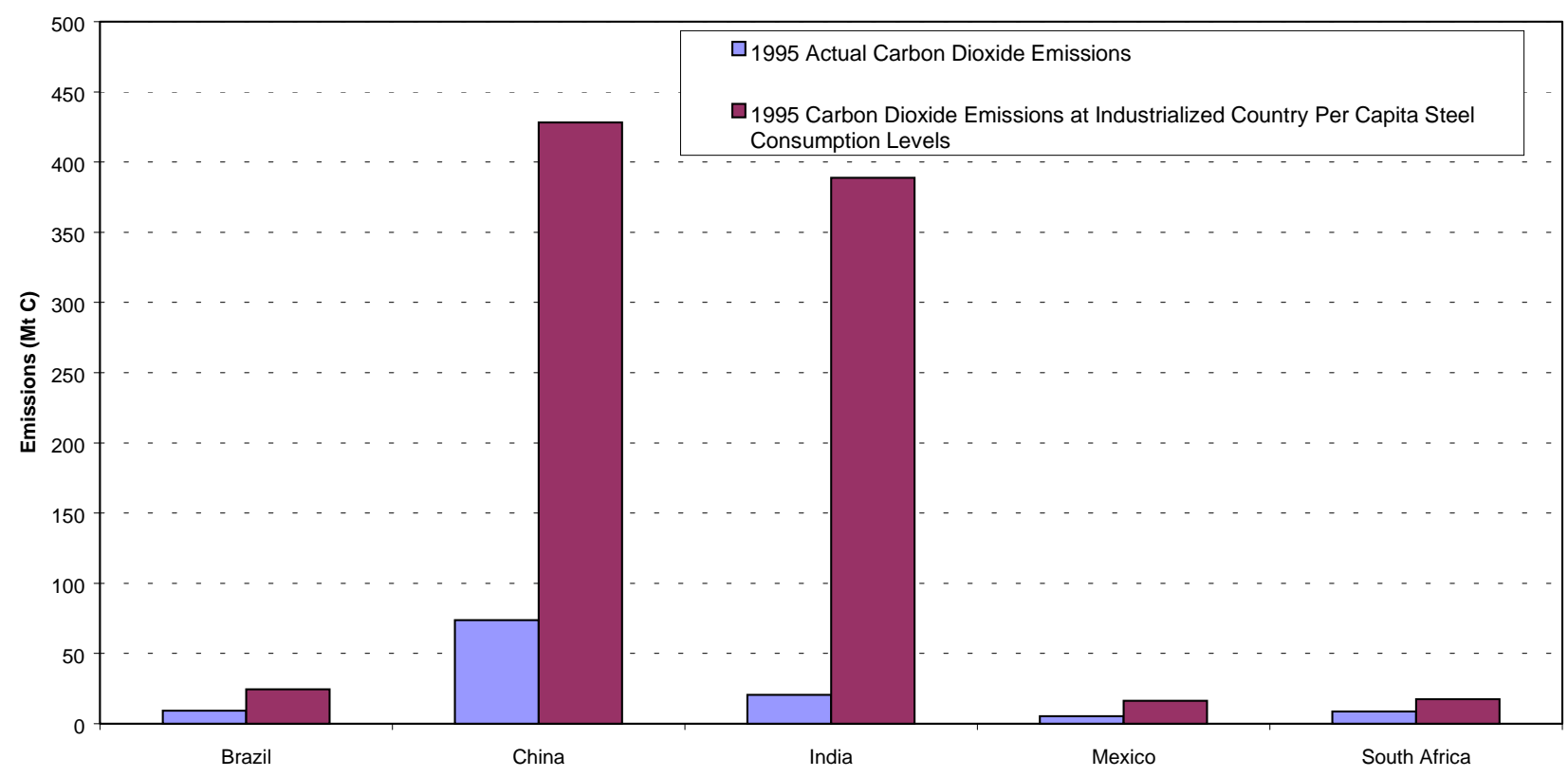




\section{Energy Use for Steelmaking}

Greenhouse gas emissions in the steel sector are primarily the result of burning fossil fuels during the production of iron and steel. Currently there are two main routes for the production of steel: production of primary steel using iron ores and scrap and production of secondary steel using scrap only. A wide variety of steel products are produced by the industry, ranging from slabs and ingots to thin sheets, which are used in turn by many other manufacturing industries. Figure 3 presents a simplified schematic of the production routes. Table 1 provides information on primary energy intensities of the key iron and steelmaking processes.

Table 1. Ranges of Primary Energy Intensities of Key Ironmaking and Steelmaking Processes (GJ/tonne steel)

\begin{tabular}{|c|c|}
\hline Process & Ranges of Primary Energy Intensity \\
\hline Ironmaking - pig iron ${ }^{1,2}$ & $12.7-18.6$ \\
\hline Ironmaking - smelt reduction ${ }^{3}$ & $13.0-18.0$ \\
\hline Ironmaking - direct reduced iron (DRI) ${ }^{4,5}$ & $10.9-16.9$ \\
\hline Steelmaking - open hearth furnace $(\mathrm{OHF})^{4,6}$ & $3.9-5.0$ \\
\hline Steelmaking - basic oxygen furnace $(\mathrm{BOF})^{1,7}$ & $0.7-1.0$ \\
\hline Steelmaking - DRI + electric arc furnace (EAF) ${ }^{4}$ & $4.0-6.7$ \\
\hline Steelmaking - scrap + electric arc furnace $(\mathrm{EAF})^{1,4,7}$ & $4.0-6.5$ \\
\hline Casting - ingot casting ${ }^{4,7,8,9,10}$ & $1.2-3.2$ \\
\hline Casting - continuous casting ${ }^{4,7,8,9,10}$ & $0.1-0.3$ \\
\hline Casting - thin slab casting ${ }^{3,5}$ & $0.6-0.9$ \\
\hline Rolling - hot rolling ${ }^{1,10}$ & $2.3-5.4$ \\
\hline Rolling - cold rolling ${ }^{1,10}$ & $1.6-2.8$ \\
\hline
\end{tabular}

Ironmaking. During the ironmaking process, sintered or pelletized iron ore is reduced using coke (produced in coke ovens) in combination with injected coal or oil to produce pig iron in a blast furnace. Limestone is added as a fluxing agent. Reduction of the iron ore is the largest energy-consuming process in the production of primary steel. In 1994, this process was responsible for over $45 \%$ of the $\mathrm{CO}_{2}$ emissions from U.S. integrated steelmaking and had a primary energy intensity of $18.6 \mathrm{GJ} /$ tonne of steel produced (including the energy used for ore preparation and cokemaking) (Worrell et al., 1999). Other countries, such as Finland and Luxembourg, use significantly less energy for ironmaking, consuming 12.7 and $12.9 \mathrm{GJ} /$ tonne, respectively (IISI, 1996b)

Smelt reduction processes are the latest development in pig iron production and omit coke production by combining the gasification of coal with the melt reduction of iron ore. Processes under development include COREX, CCF, DIOS, AISI, and HISmelt. Currently, only the COREX process (Voest-Alpine, Austria) is commercial and operating in South Africa and South Korea, with plants under construction in India, South Korea, and South Africa (Voest Alpine Industrieanlagenbau, 1996). The COREX process uses agglomerated ore, which is pre-reduced by gases coming from a hot bath. The pre-reduced iron is then melted in the bath. The process produces excess gas, which is used for power generation, DRI-production, or as fuel gas. The COREX process is estimated to use 15 to $18 \mathrm{GJ} /$ tonne steel net energy consumption, while the CCF process is estimated to use $13 \mathrm{GJ} /$ tonne steel net energy consumption (Worrell and Moore, 1997).

Direct reduced iron (DRI), hot briquetted iron (HBI,) and iron carbide are all alternative iron making processes (McAloon, 1994). Direct reduced iron (DRI), also called sponge iron, is produced by reduction of the ores below the melting point in small-scale plants $(<1$ Mtonnes/year) and has different properties than pig iron. Production of DRI typically requires between 10.9 and $16.9 \mathrm{GJ} /$ tonne of steel, including the energy used for ore preparation (WEC, 1995; IISI, 1998a). DRI production is growing and nearly $4 \%$ of the iron in the world is produced by direct reduction, of which over $90 \%$ uses natural gas as a fuel (Midrex, 1995). DRI serves as a high-quality alternative for scrap in secondary steelmaking (see below). 
Figure 3. Iron and Steelmaking Production Routes and Typical Primary Energy Intensities (GJ/tonne).

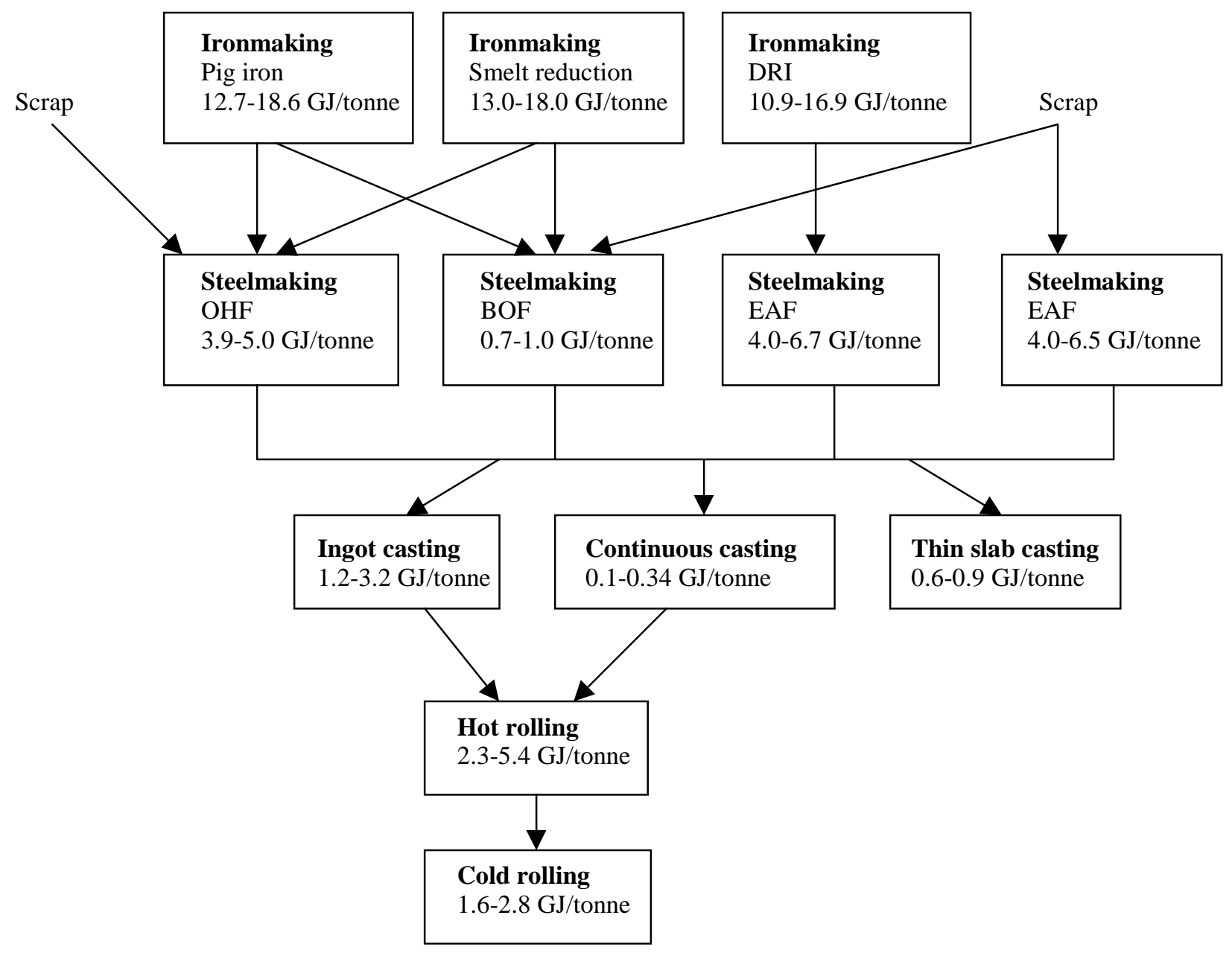

\begin{tabular}{l|c}
\hline Iron/Steelmaking Process & $\begin{array}{c}\text { Example Primary } \\
\text { Energy Intensity } \\
\text { (GJ/tonne)* }\end{array}$ \\
\hline Pig Iron/OHF/Ingot Casting/Hot Rolling & 26.2 \\
Pig Iron/BOF/Ingot Casting/Hot Rolling & 22.6 \\
Pig Iron/BOF/Continuous Casting/Hot Rolling & 20.6 \\
Pig Iron/BOF/Thin Slab Casting & 17.3 \\
\hline Smelt Reduction/BOF/Ingot Casting/Hot Rolling & 22.4 \\
Smelt Reduction/BOF/Continuous Casting/Hot Rolling & 20.4 \\
Smelt Reduction/BOF/Thin Slab Casting & 17.1 \\
\hline DRI/EAF/Continuous Casting/Hot Rolling & 23.3 \\
DRI/EAF/Thin Slab Casting & 20.0 \\
\hline EAF/Continuous Casting/Hot Rolling & 9.3 \\
EAF/Thin Slab Casting & 6.0 \\
\hline
\end{tabular}

*Using the mid-point of each range. 
Primary steel is produced by two processes: open hearth furnace (OHF) and basic oxygen furnace (BOF). Steelmaking using a basic oxygen furnace (BOF) has a relatively low energy intensity (0.7-1.0 GJ/tonne) compared to the 3.9-5.0 GJ/tonne energy intensity of open hearth furnaces (OHFs), which are much more common in developing countries (Energetics, 2000; Kundrin, 1985; WEC, 1995; Worrell et al, 1999). The OHF is still used in Eastern Europe, China, India and other developing countries, although its complete phase-out was planned for the end of 2000 in China (Li and Wang, 1999). While OHF uses more energy, this process can also use more scrap than the BOF process. However, the BOF process is rapidly replacing the OHF worldwide, because of its greater productivity and lower capital costs (IISI, 1990). In addition, this process needs no net input of energy and can even be a net energy exporter in the form of BOF-gas and steam. The process operates through the injection of oxygen, oxidizing the carbon in the hot metal. Several configurations exist depending on the way the oxygen is injected. The steel quality can be improved further by ladle refining processes used in the steel mill. The scrap input is rather small for the BOF-route, typically about $10-25 \%$.

Secondary steel is produced in an electric arc furnace (EAF) using scrap. In this process, the coke production, pig iron production, and steel production steps are omitted, resulting in much lower energy consumption and a primary energy intensity of 4.0-6.5 GJ/tonne (Energetics, 2000; WEC, 1995; Worrell et al., 1999). To produce secondary steel, scrap is melted and refined, using a strong electric current. The EAF can also be fed with iron from the direct reduced iron (DRI) route, but energy consumption may increase slightly due to the added carbon, resulting in an EAF primary energy intensity of 4.0-6.7 GJ/tonne (WEC, 1995). DRI is used to enhance steel quality or if high quality scrap is scarce or expensive. Several process variations exist, using either AC or DC currents, and fuels can be injected to reduce electricity use. Energy optimizing furnaces (EOFs) can also be used to produce steel from scrap. This process is essentially an oxygen steelmaking process using combined side blowing. The heat from the carbon-oxygen reaction is used to preheat scrap (Chatterjee, 1996).

Casting can be a batch (ingots) or a continuous process (slabs, blooms, billets). Ingot casting is the classical process and is rapidly being replaced by continuous casting machines (CCM). In 1998, 83\% of global crude steel production was cast continuously (IISI, 1999). Continuous casting is a significantly more energy-efficient process for casting steel than the older ingot casting process. Continuous casting uses 0.1-0.34 GJ/tonne of steel, significantly less than the 1.2-3.2 GJ/tonne required for ingot casting (Brown et al., 1985; Energetics, 1988; Energetics, 2000; WEC, 1995; Worrell et al., 1993).

Rolling of the cast steel begins in the hot rolling mill where the steel is heated and passed through heavy roller sections reducing the thickness of the steel. Hot rolling typically consumes between 2.3 and $5.4 \mathrm{GJ} /$ tonne of steel (Worrell et al., 1993; Worrell et al., 1999). The sheets may be further reduced in thickness by cold rolling. Finishing is the final production step, and may include different processes such as annealing, pickling, and surface treatment. Cold rolling and finishing add 1.6-2.8 GJ/tonne to the rolling energy use (Worrell et al., 1993; Worrell et al., 1999).

Thin slab or near net shape casting are more advanced casting techniques which reduce the need for hot rolling because products are intially cast closer to their final shape. Primary energy used for casting and rolling using thin slab casting is 0.6-0.9 GJ/tonne (IISI, 1998a; Worrell and Moore, 1997). 


\section{Historical Production Trends by Process}

\section{A. Ironmaking}

The growth of iron production varies strongly by country and by time period. Figures 4 and 5 show pig iron and DRI/HBI production for the five key developing countries. Figure 4 and Table 2 show that China is the world's largest iron producer, producing $118.6 \mathrm{Mt}$ in 1998, more than four times more than the next largest producer among developing countries, Brazil.

Table 3 shows that Brazil experienced the largest average annual growth in iron production between 1970 and 1980, but that this growth has dropped dramatically since the mid-1980s, when both Brazil and Mexico clearly suffered from the economic crisis in Latin America. Growth in iron production in China was greatest between 1990 and 1995, averaging over 11\% per year, but this growth slowed to just over 4\% per year between 1995 and 1998. The very high growth rates for some countries in the first two periods listed in Table 3 are mainly caused by the low absolute amount of iron production in the early 1970s. During these periods, almost the entire steel production was comprised of EAF steel using steel scrap as input. Pig iron, from either blast furnaces or from the COREX process, is the predominant type of iron produced in these five countries. Currently, only Mexico and India produce significant amounts of iron using the DRI/HBI processes. In Mexico, the DRI/HBI steel is produced using natural gas as a fuel while in India 60\% of current DRI capacity is natural gas-based, and in South Africa this steel is produced predominately using coal as a fuel.

Table 2. Iron Production in 1971 and 1998 by Type in Five Key Developing Countries (Mtonnes)

\begin{tabular}{l|c|c|c|c}
\hline & \multicolumn{2}{|c|}{ Pig Iron } & \multicolumn{2}{c}{ DRI/HBI } \\
\hline Country & $\mathbf{1 9 7 1}$ & $\mathbf{1 9 9 8}$ & $\mathbf{1 9 7 1}$ & $\mathbf{1 9 9 8}$ \\
\hline Brazil & 4.8 & 25.1 & 0.0 & 0.34 \\
China & 21.0 & 118.6 & 0.0 & 0.08 \\
India & 6.9 & 19.4 & 0.0 & 5.12 \\
Mexico & 1.7 & 4.5 & 0.6 & 5.52 \\
South Africa $^{1}$ & 8.1 & 5.7 & 0.1 & 1.05 \\
\hline
\end{tabular}

Notes: ${ }^{1}$ data for South Africa are from 1980 instead of 1971.

Sources: IISI, various years; IISI, 1997; IISI, 1999; Sinters and Pellets Magazine, 1999; SPP, 1980 .

Table 3. Average Annual Growth Rates (\%) for Iron Production in Five Key Developing Countries

\begin{tabular}{l|c|c|c|c|c|c|c}
\hline Country & $\mathbf{1 9 7 0 - 1 9 7 5}$ & $\mathbf{1 9 7 5 - 1 9 8 0}$ & $\mathbf{1 9 8 0 - 1 9 8 5}$ & $\mathbf{1 9 8 5 - 1 9 9 0}$ & $\mathbf{1 9 9 0 - 1 9 9 5}$ & $\mathbf{1 9 9 5 - 1 9 9 8}$ & $\mathbf{1 9 7 0 - 1 9 9 8}$ \\
\hline Brazil & $11.1 \%$ & $12.2 \%$ & $8.3 \%$ & $2.1 \%$ & $3.5 \%$ & $0.1 \%$ & $6.6 \%$ \\
China & $7.5 \%$ & $9.2 \%$ & $2.9 \%$ & $7.3 \%$ & $11.1 \%$ & $4.1 \%$ & $7.2 \%$ \\
India & $3.8 \%$ & $0.4 \%$ & $2.7 \%$ & $4.9 \%$ & $13.0 \%$ & $1.8 \%$ & $4.5 \%$ \\
Mexico & $5.6 \%$ & $12.3 \%$ & $-0.5 \%$ & $3.9 \%$ & $4.4 \%$ & $7.9 \%$ & $5.3 \%$ \\
South Africa & - & - & 2.4 & -9.8 & $5.2 \%$ & $3.6 \%$ & $-0.3 \%{ }^{1}$ \\
\hline
\end{tabular}

Notes: ${ }^{1}$ annual average growth rate between 1980-1998 for South Africa.

Sources: IISI various years; IISI, 1992; IISI, 1997; Sinters and Pellets Magazine, 1999; SPP, 1980. 
Figure 4. Pig Iron Production in Five Key Developing Countries

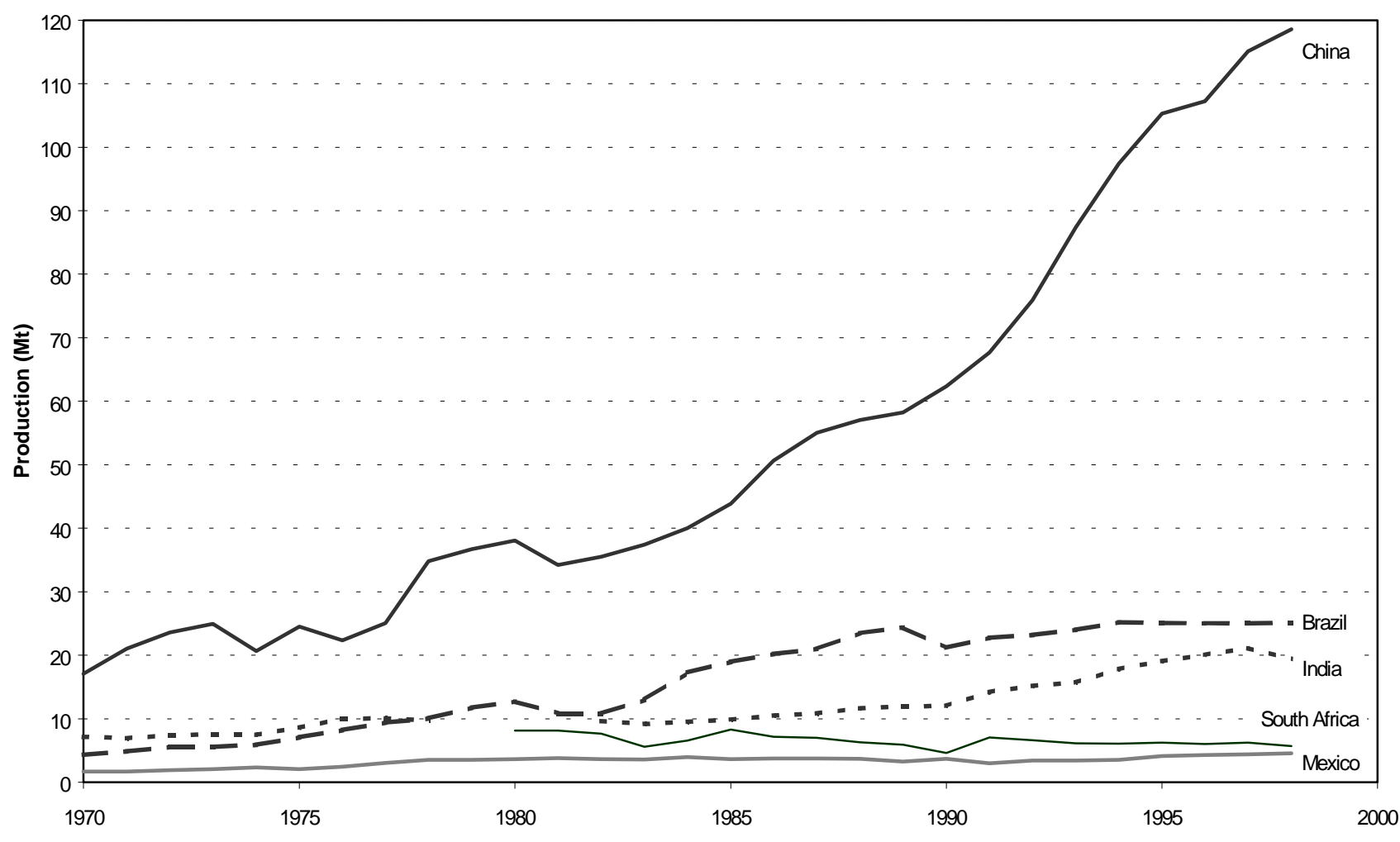

Figure 5. DRI/HBI Iron Production in Five Key Developing Countries

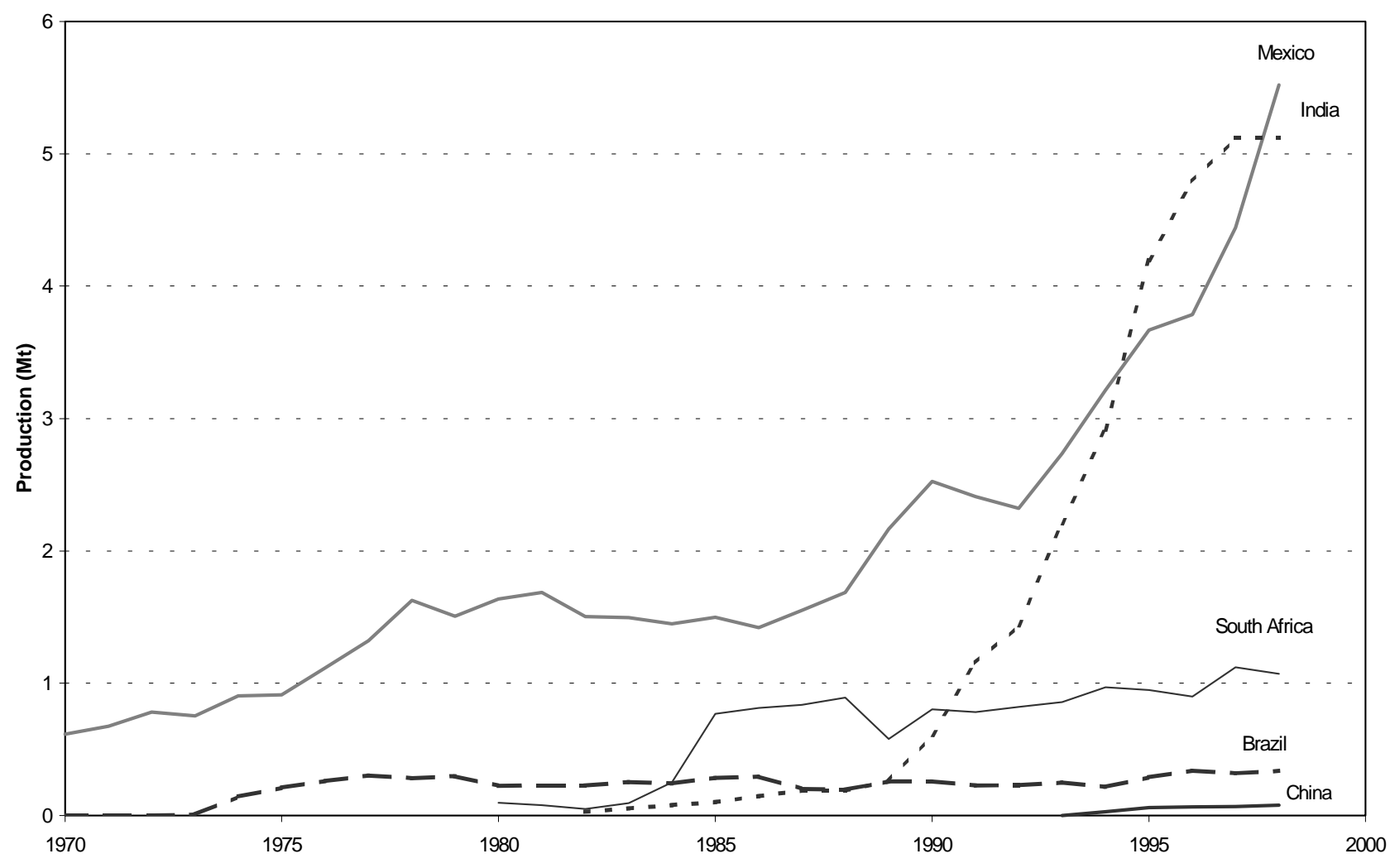




\section{B. Steelmaking}

Historical trends in steel production from 1970 to 1998 for the five key developing countries are presented in Figure 6. As with iron production, China clearly dominates in steel production among these five developing countries (as well as globally). In 1996, China became the world's largest steel producer, passing Japan and the U.S. (IISI, 1999). Average annual growth rates by period and for 1970 through 1998 are listed in Table 4 . The highest growth over the 1970 to 1998 period was seen in China (6.4\%), followed by Brazil (5.8\%), India (4.9\%), Mexico (4.7\%), and South Africa (1.7\%), respectively.

Table 4. Average Annual Growth Rates for Steel Production in Five Key Developing Countries

\begin{tabular}{l|c|c|c|c|c|c|c}
\hline Country & $\mathbf{1 9 7 0 - 1 9 7 5}$ & $\mathbf{1 9 7 5 - 1 9 8 0}$ & $\mathbf{1 9 8 0 - 1 9 8 5}$ & $\mathbf{1 9 8 5 - 1 9 9 0}$ & $\mathbf{1 9 9 0 - 1 9 9 5}$ & $\mathbf{1 9 9 5 - 1 9 9 8}$ & $\mathbf{1 9 7 0 - 1 9 9 8}$ \\
\hline Brazil & $9.3 \%$ & $12.8 \%$ & $6.0 \%$ & $0.1 \%$ & $4.0 \%$ & $1.0 \%$ & $5.8 \%$ \\
China & $2.9 \%$ & $9.2 \%$ & $4.7 \%$ & $7.2 \%$ & $7.6 \%$ & $6.2 \%$ & $6.4 \%$ \\
India & $5.0 \%$ & $3.5 \%$ & $4.7 \%$ & $4.6 \%$ & $6.8 \%$ & $4.8 \%$ & $4.9 \%$ \\
Mexico & $6.3 \%$ & $6.3 \%$ & $0.7 \%$ & $3.4 \%$ & $6.8 \%$ & $5.1 \%$ & $4.7 \%$ \\
South Africa & $7.5 \%$ & $5.8 \%$ & $-1.3 \%$ & $0.3 \%$ & $0.2 \%$ & $-4.0 \%$ & $1.7 \%$ \\
\hline
\end{tabular}

Sources: IISI, 1997; IISI, 1998b; IISI, 1999; Ministry of Metallurgical Industry, 1994; OECD, 1995.

Historical trends in the use of different steel production processes for the five developing countries are shown in Figures 7 to 11. Table 5 provides information on the shares of OHF, BOF, and EAF production in each of these countries in 1998. The OHF process typically uses $3.2 \mathrm{GJ} /$ tonne crude steel more energy than the BOF process. OHFs were phased out in Brazil by 1989 and in Mexico by in 1992. In both countries, a sharp decline in the share of OHFs started in the mid-seventies when stronger growth in new steel capacity was accompanied by a gradual shutdown of old OHF capacity. The share of OHF in total production has also been declining over time in China and India, with China's last OHFs scheduled for closure in late 2000 ( $\mathrm{Li}$ and Wang, 1999). The share of EAF steelmaking grew steadily in India, Mexico, and South Africa, but declined slightly in Brazil and China around 1995 only to grow again by 1997/98.

Table 5. Share of OHF, BOF, and EAF Steelmaking in Five Developing Countries in 1998

\begin{tabular}{l|c|c|c|c}
\hline Country & Share of OHF & Share of BOF & Share of EAF & Share of Other* \\
\hline Brazil & $0 \%$ & $79 \%$ & $20 \%$ & $1 \%$ \\
China & $5 \%$ & $75 \%$ & $20 \%$ & $0 \%$ \\
India & $14 \%$ & $54 \%$ & $32 \%$ & $0 \%$ \\
Mexico & $0 \%$ & $35 \%$ & $65 \%$ & $0 \%$ \\
South Africa & $0 \%$ & $64 \%$ & $36 \%$ & $0 \%$ \\
\hline
\end{tabular}

Sources: IISI, 1999.

* The category of "other" in Brazil consists of Energy Optimizing Furnaces (EOF).

\section{Casting}

Continuous casting is significantly more energy-efficient than ingot casting, typically saving $1.85 \mathrm{GJ} /$ tonne crude steel cast. The share of continuous casting has increased significantly in all five countries since 1970. Figure 12 shows that South Africa has the highest share of continuous casting (96\% in 1998) among the five countries. The share of continuous casting grew to $80 \%$ and $86 \%$ by 1998 in Brazil and Mexico, respectively. In China $68 \%$ of the steel was continuously cast in 1998, while India's share of continuous casting was 50\% that year (IISI, 1999).

\section{Rolling}

After casting, steel is further rolled to produce sheet, strip, plate, and other structural products. Hot rolling typically uses $5.4 \mathrm{GJ} /$ tonne crude steel. Some steel is further cold rolled and finished to make a thinner and smoother product. This cold rolling and finishing typically adds $1.85 \mathrm{GJ} /$ tonne. Figure 13 shows that the share of more energyintensive cold rolled products is increasing, especially in Brazil, India, and, since 1995, Mexico.

\footnotetext{
${ }^{2}$ Measured as the amount of cold-rolled products divided by total crude steel production.
} 
Figure 6. Historical Steel Production in Five Key Developing Countries

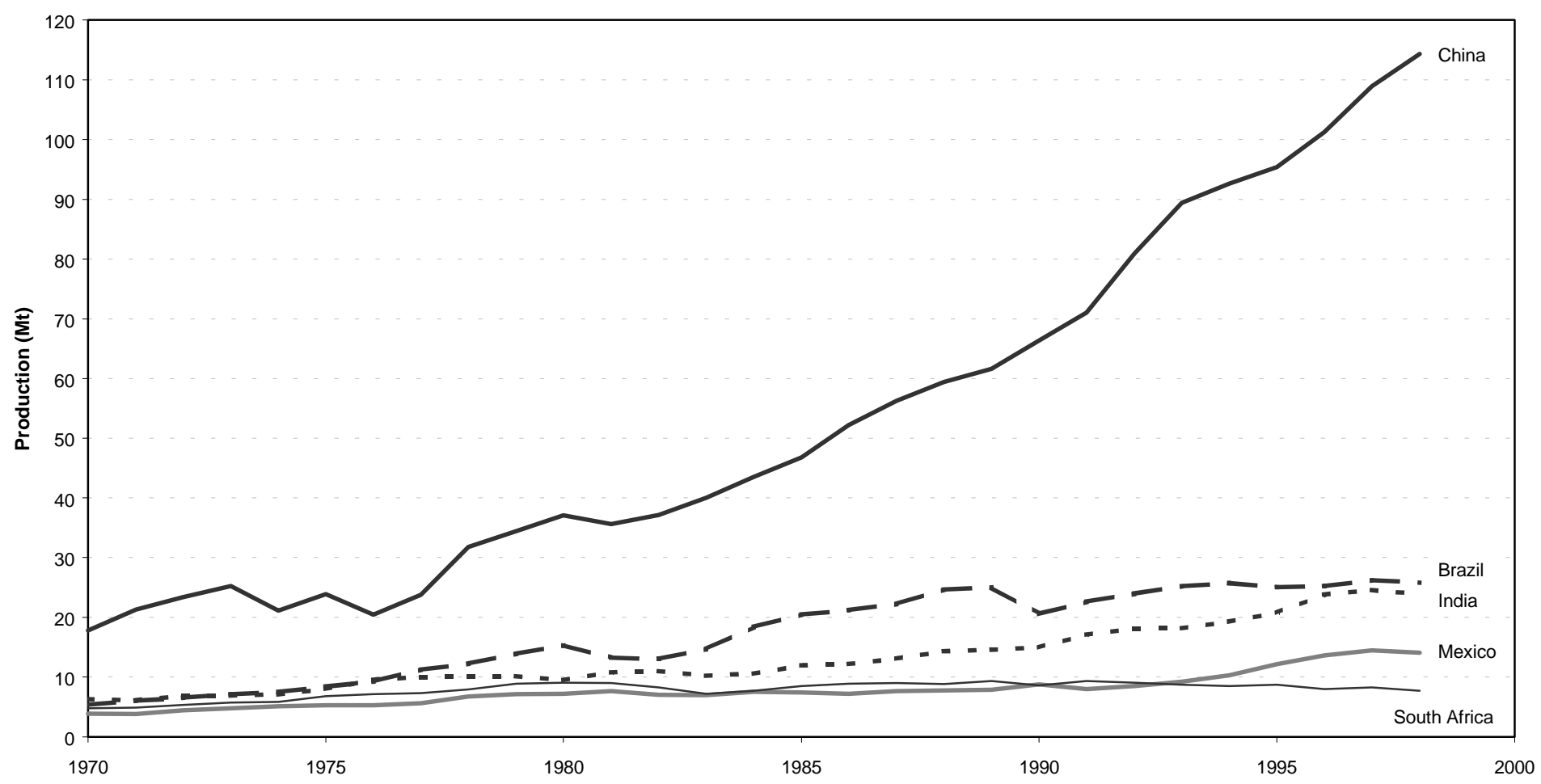

Figure 7. Steel Production by Process: Brazil

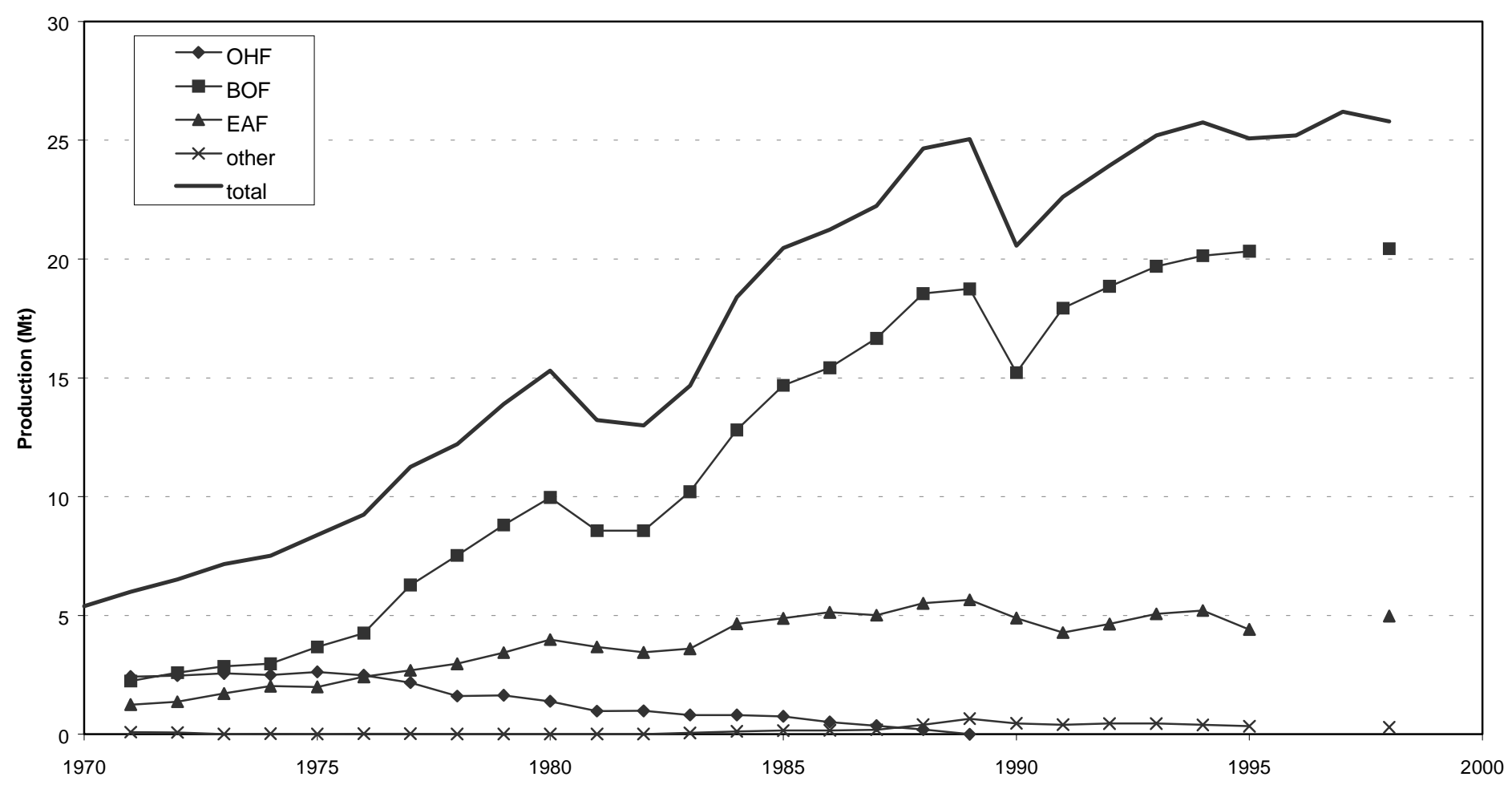


Figure 8. Steel Production by Process: China

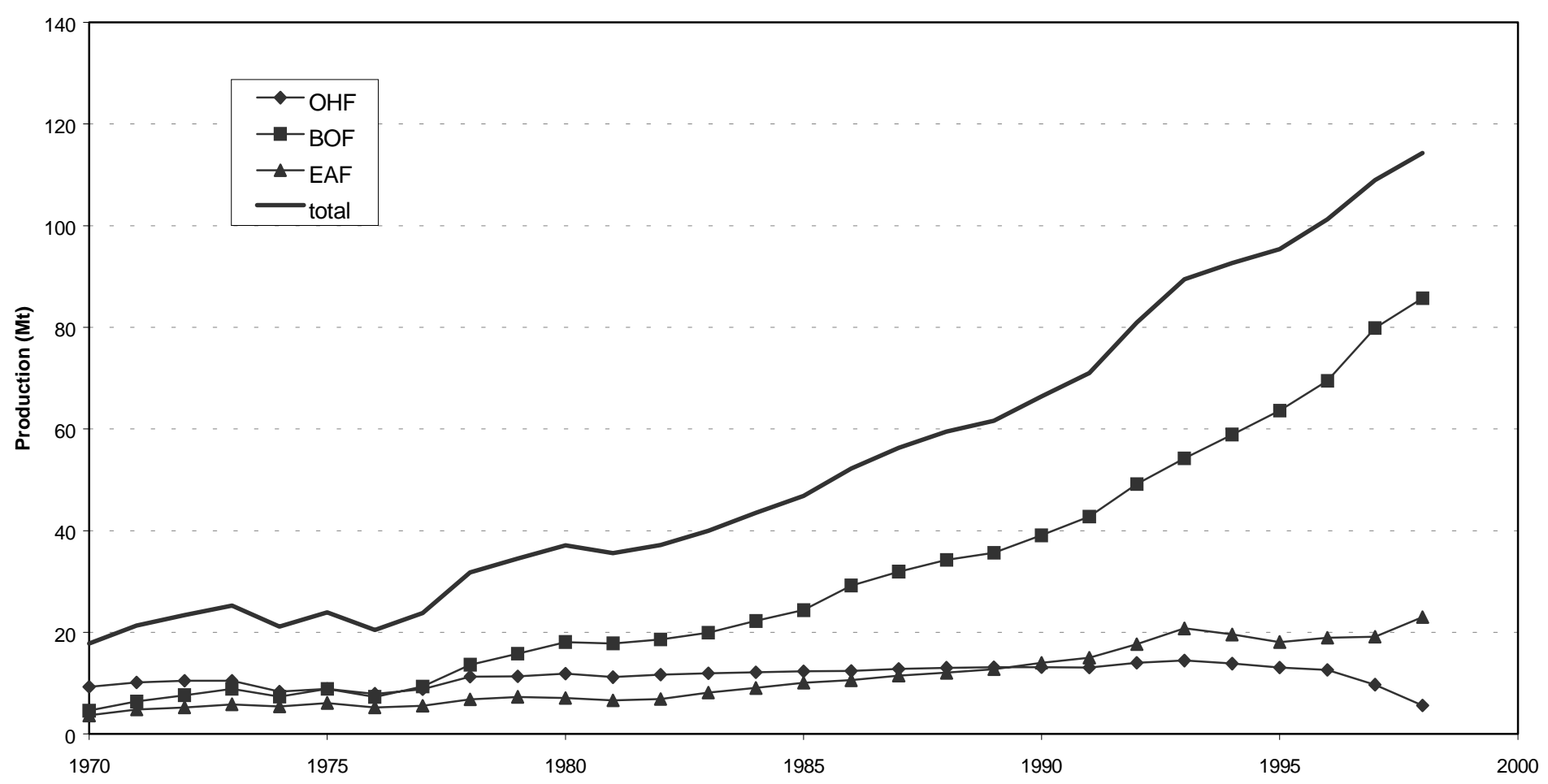

Figure 9. Steel Production by Process: India

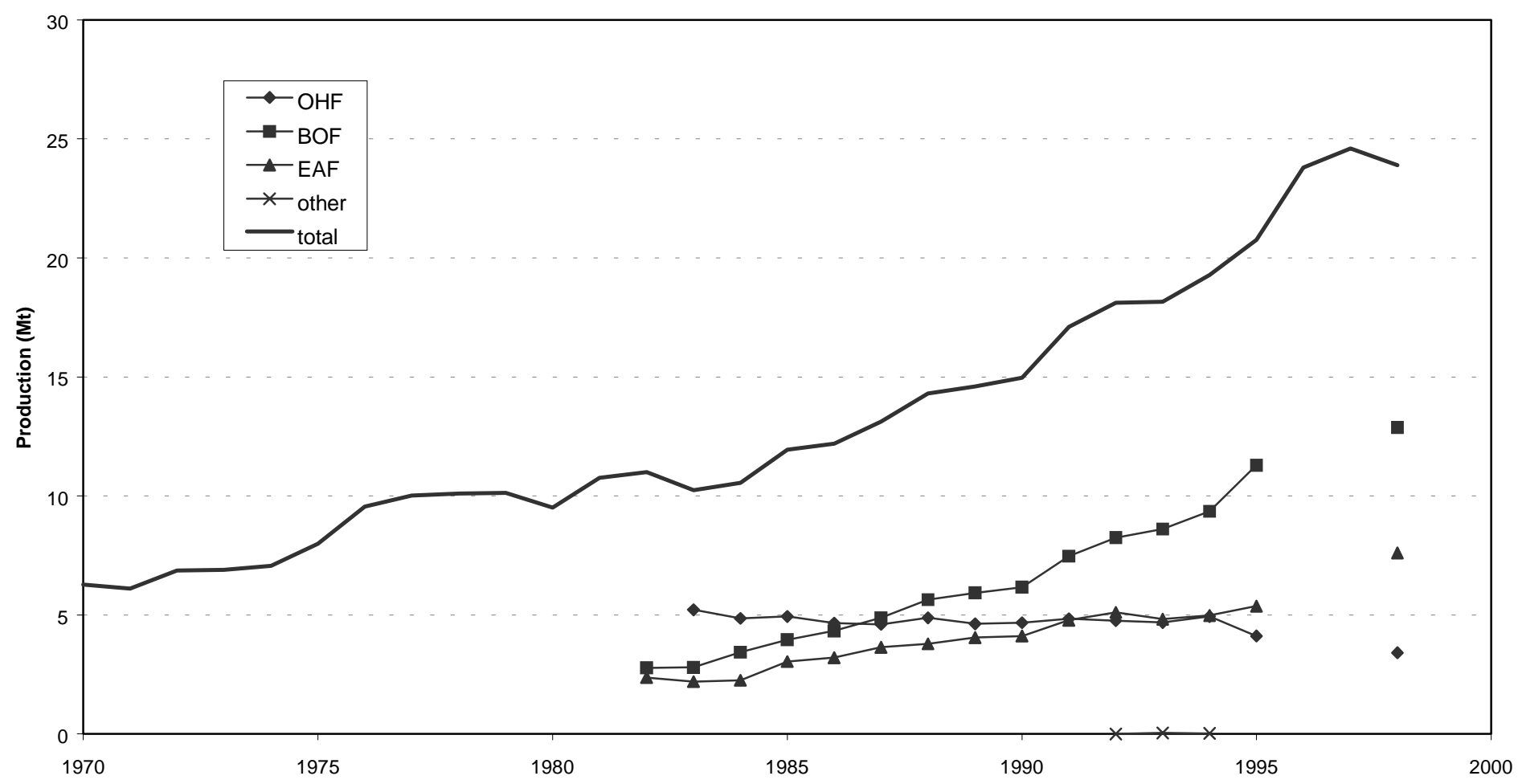


Figure 10. Steel Production by Process: Mexico

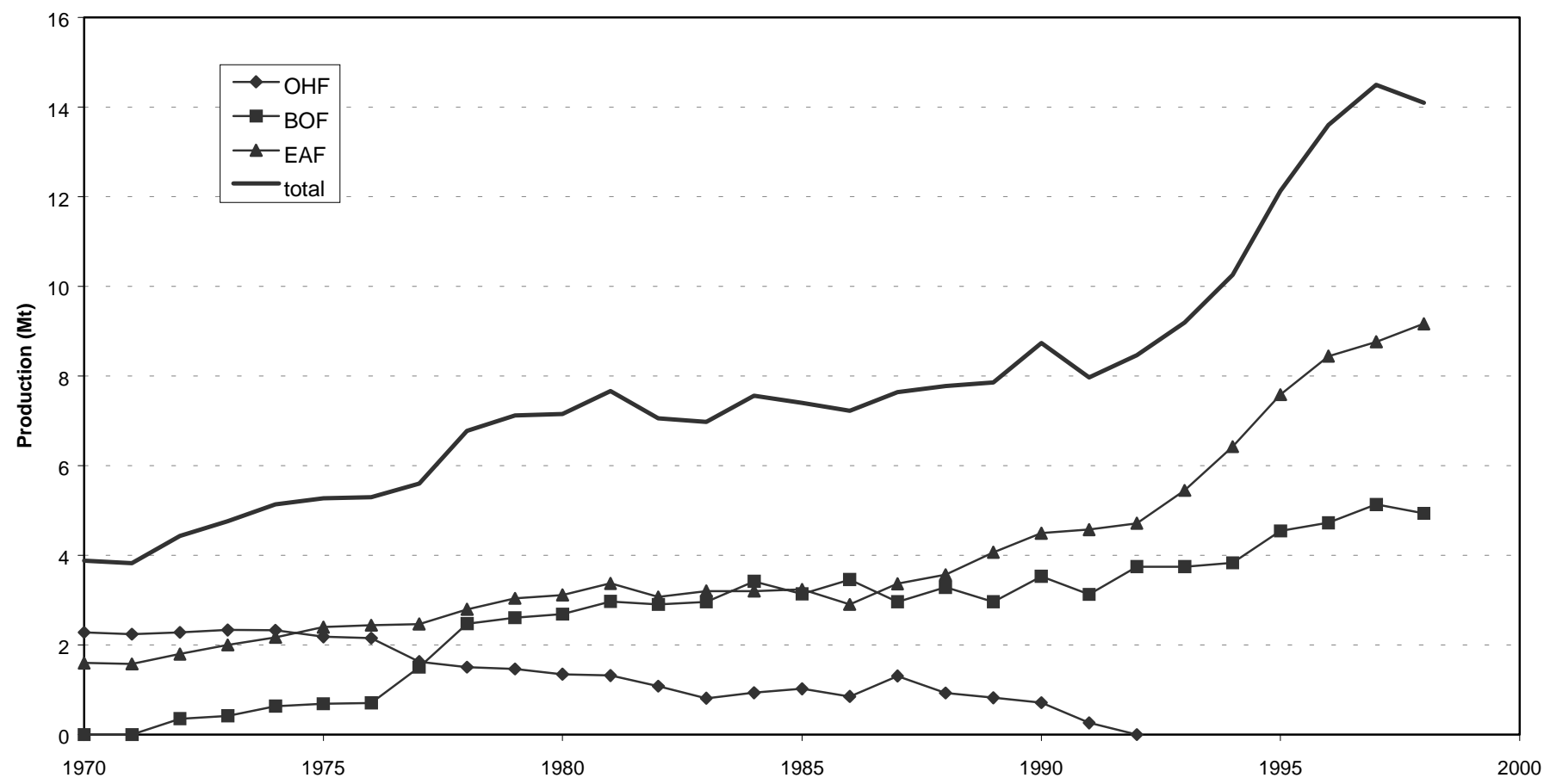

Figure 11. Steel Production by Process: South Africa

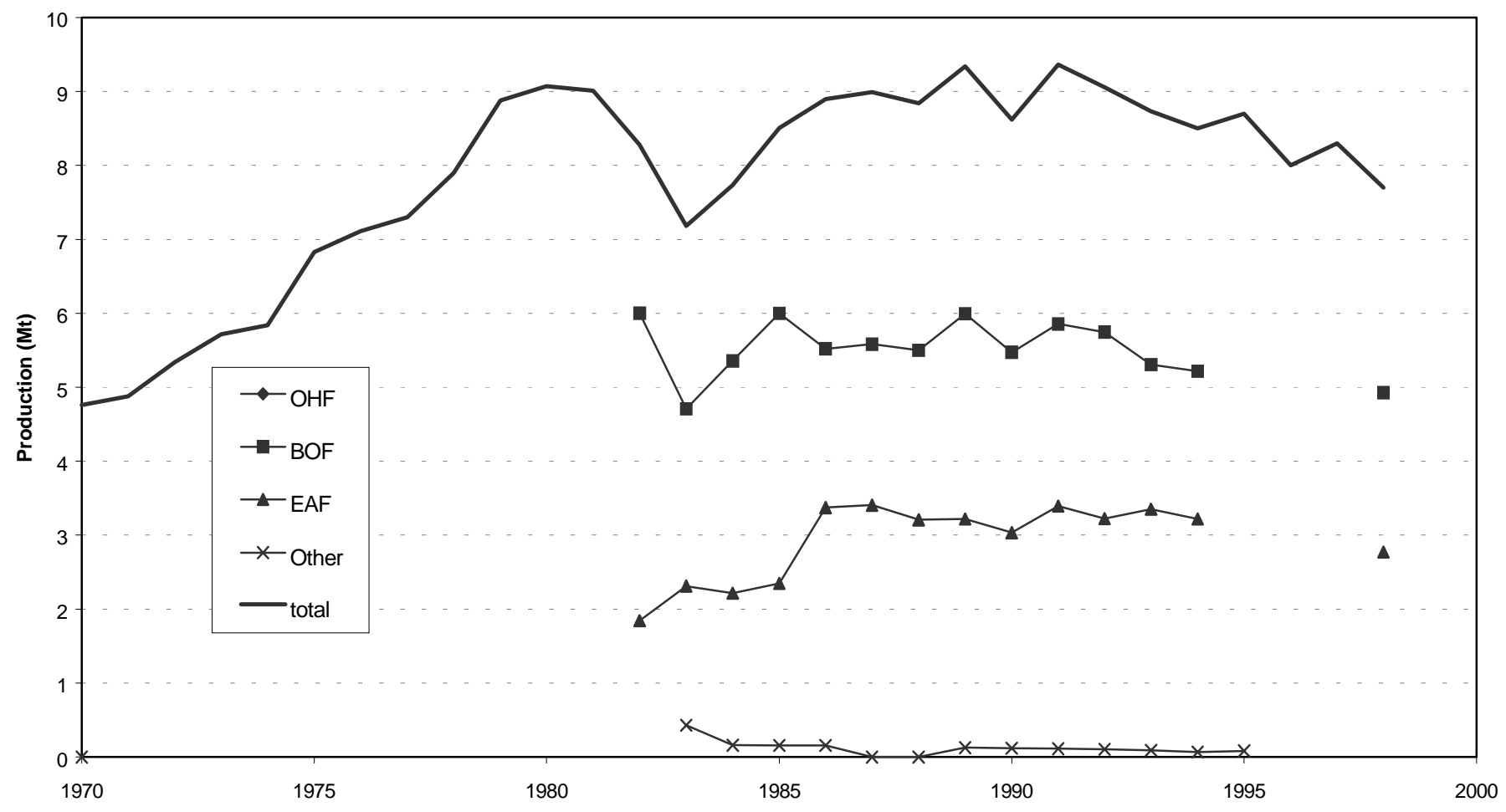


Figure 12. Share of Continuously Cast Steel in Total Crude Steel Production: 1970-1998

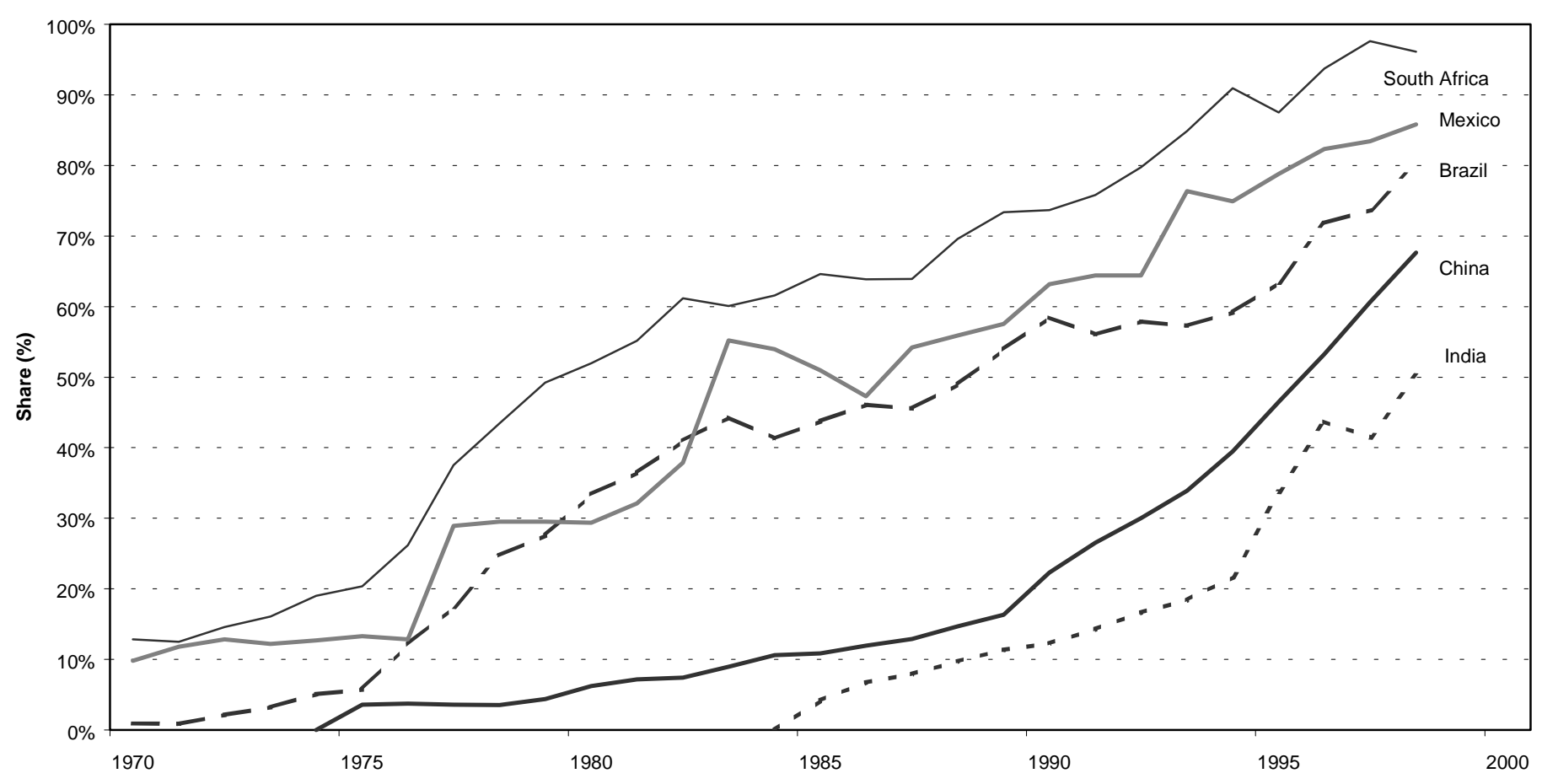

Figure 13. Share of Cold Rolled Steel

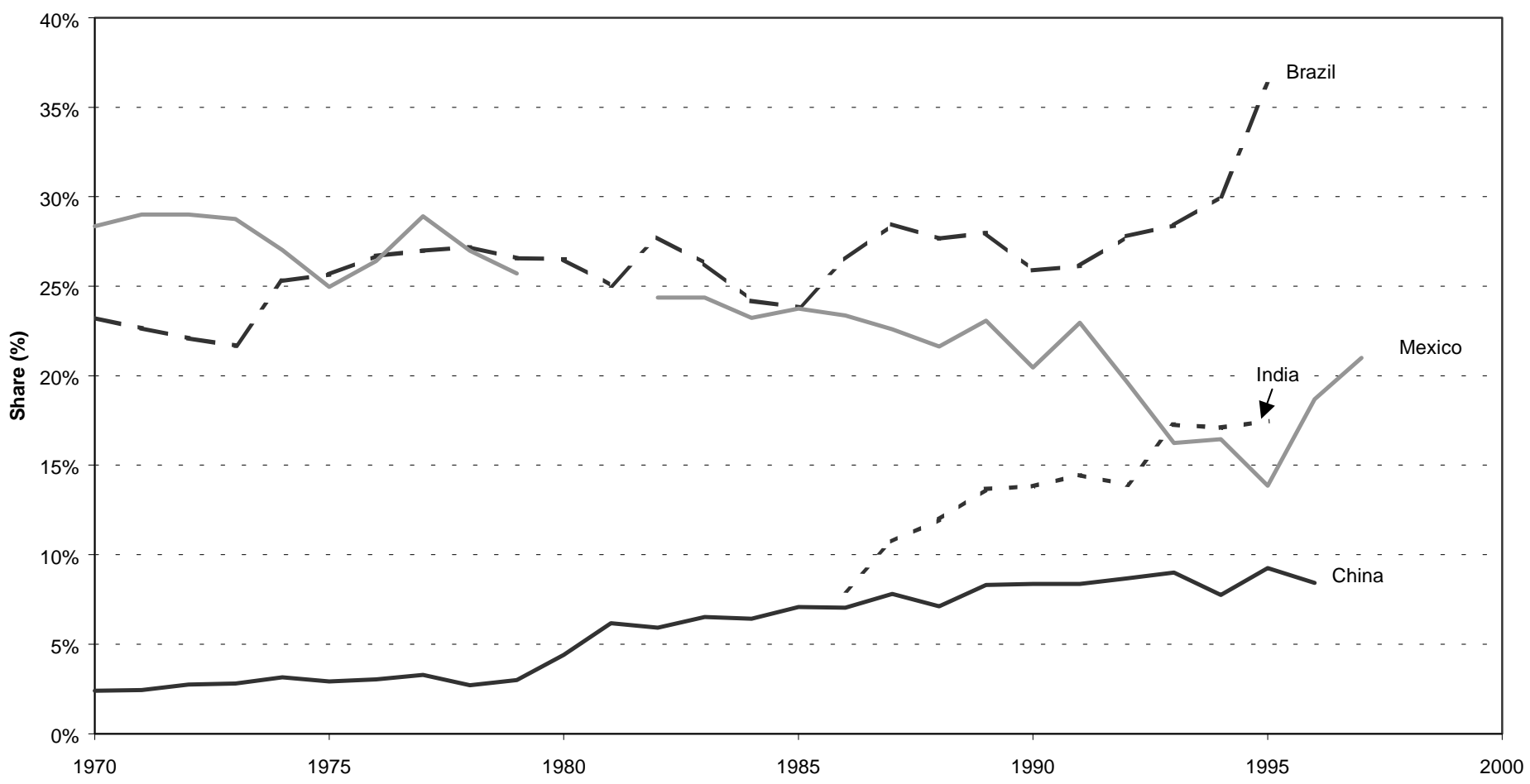




\section{Country-Specific Information on Steel Manufacturing}

\section{A. Brazil}

The first large integrated steel mill in Brazil was built during World War II and was followed by construction of a number of plants, both state-owned and private, during the post-war economic boom. Production increased dramatically in the 1970s, at average annual rates over $10 \%$, due to increased demand for steel from the automobile industry as well as domestic infrastructure projects. The economic crisis during the 1980s led to a drop in production between 1980 and 1982, from 15.3 Mt to 13.0 Mt, but growth resumed in 1983, peaking at $25 \mathrm{Mt}$ in 1989. Production has remained relatively constant since then (de Araújo, n.d.; LBNL, 1999).

In 1996, the Brazilian iron and steel industry consisted of 20 companies operating about 35 plants that produced slightly over $25 \mathrm{Mt}$ of crude steel (see Table 6) (de Araújo, n.d.; IBS, 1997). Almost 80\% of the crude steel is primary steel produced using basic oxygen furnaces. Of the remaining $20 \%$, all of the companies except one use electric arc furnaces to produce secondary steel from scrap. One company, Pains, used an energy optimization furnace (EOF) to produce $0.4 \mathrm{Mt}$, or $1 \%$ of total Brazilian steel production, in 1996. Continuous casting was used to cast $72 \%$ of the crude steel produced in 1996 (IBS, 1997). The industry predominately produces common flat steel products, but is becoming more diversified, increasing the production of high value added semi-finished products in recent years. Both pig iron plants and integrated steel plants use charcoal in Brazil, which is an unusual feature of the Brazilian steel industry. Charcoal use results in lower sulphur emissions and low slag generation, but presents problems because only a relatively small fraction of charcoal is made with wood from sustainable and managed forests (Costa and Schaeffer, 1997). In 1996, about 25\% of the pig iron produced in Brazil was made using charcoal in the blast furnace (IBS, 1997). The five companies that use charcoal in the blast furnace are Acesita, Açonorte, Belgo Mineira, Mannesman, and Pains. One company (Açonorte) produced $0.335 \mathrm{Mt}$ of sponge iron through direct reduction (IBS, 1997).

Five companies, which formerly comprised the state-owned Siderbras (which was broken up and privatized in 1990), are integrated steel producers that use coal as a reducer in the blast furnaces and basic oxygen furnaces to produce crude steel. These five companies (Acominas, Cosipa, CSN, CST, and Usiminas), produced slightly over $71 \%$ of the total crude steel in Brazil in 1996 (de Araújo, n.d.; IBS, 1997). Almost 40\% of the steel produced in Brazil was exported in 1996. This steel is shipped to over 70 countries; the largest importers are the U.S. (2.7 Mt), Thailand (0.9 Mt), South Korea (0.9 Mt), and Taiwan (0.8 Mt) (IBS, 1997).

Table 6. Crude Steel Production by Company/Plant in Brazil, 1996

\begin{tabular}{|c|c|c|c|c|}
\hline Company/Plant & $\begin{array}{c}\text { Steelmaking } \\
\text { Process }\end{array}$ & $\begin{array}{c}\text { Year } \\
\text { Established }\end{array}$ & $\begin{array}{c}\text { Continuously } \\
\text { Cast Steel }\end{array}$ & $\begin{array}{c}1996 \text { Crude Steel } \\
\text { Production } \\
\text { (Mtonnes) }\end{array}$ \\
\hline Acesita & $\mathrm{BOF}+\mathrm{EAF}$ & 1944 & yes & 0.6 \\
\hline Açominas & $\mathrm{BOF}$ & 1966 & no & 2.4 \\
\hline Açonorte (Gerdau) & $\mathrm{BOF}+\mathrm{EAF}$ & 1958 & yes & 0.6 \\
\hline Acos Villares & EAF & 1966 & no & 0.6 \\
\hline Barra Mansa & EAF & 1937 & yes & 0.4 \\
\hline Belgo Mineira & $\mathrm{BOF}+\mathrm{EAF}$ & 1921 & yes & 1.0 \\
\hline CBAco & EAF & 1943 & no & 0.04 \\
\hline Copala & EAF & 1950 & no & 0.001 \\
\hline Cosigua & $\mathrm{BOF}+\mathrm{EF}$ & 1961 & yes & 1.2 \\
\hline Cosipa & $\mathrm{BOF}$ & 1953 & yes & 3.6 \\
\hline $\mathrm{CSN}$ & $\mathrm{BOF}$ & 1941 & yes & 4.4 \\
\hline CST & BOF & 1983 & yes & 3.6 \\
\hline Dedini & EAF & 1955 & yes & 0.4 \\
\hline Itaunense & EAF & 1963 & yes & 0.1 \\
\hline Mannesman & $\mathrm{BOF}$ & 1952 & yes & 0.5 \\
\hline Mendes Jr. & EAF & 1984 & yes & 0.7 \\
\hline Pains & EOF & 1953 & yes & 0.4 \\
\hline Riograndense & EAF & 1938 & yes & 0.7 \\
\hline Usiminas & $\mathrm{BOF}$ & 1957 & yes & 4.0 \\
\hline Villares & EAF & 1975 & yes & 0.1 \\
\hline $\begin{array}{l}\text { Total Integrated Steel Production } \\
\text { Total Secondary Steel Production }\end{array}$ & & & & $\begin{array}{r}20.1 \\
5.1\end{array}$ \\
\hline Total Crude Steel Production & & & $72 \%$ & 25.2 \\
\hline
\end{tabular}

Notes: Table excludes Mafersa, a small steel company that produced 16 ktonnes in 1996 destined exclusively for casting (IBS, 1997).

Sources: de Araújo, n.d.; IBS, 1997. 


\section{B. China}

Expansion of China's steel industry was a major objective during the years of central planning from the 1950s to the 1980 s, and growth remained strong during the market reforms of the 1990s. The Chinese steel industry continues to grow rapidly, and in 1996 China became the world's largest producer of steel (IISI, 1999). China has been one of the few countries to construct new integrated primary steel plants recently (Worrell, 1995). There are currently 33 key iron and steel enterprises in China operated by the Ministry of Metallurgical Industry (MMI). These key enterprises produced $68 \mathrm{Mt}$ of crude steel in 1997 (see Table 7). These plants are generally old, ranging in age from 17 to 89 years old and averaging 48 years old (although the age of the plant does not give adequate information regarding later equipment upgrades). Overall, continuous casting is used for $57 \%$ of the steel produced by these key plants.

Along with these key enterprises, MMI supervised an additional 56 major local iron and steel enterprises that produced $30 \mathrm{Mt}$, or 27\%, of crude steel in 1997. Over two-thirds of these plants were built in the 1950s; the most recently constructed plant was built in 1972. Continuous casting is used for $79 \%$ of the steel produced in these plants (MMI, 1998). A small percentage of steel is produced by small enterprises in the MMI system. These plants mainly operate small EAFs, or produce only iron. Some steel is manufactured in non-MMI enterprises, i.e., iron and steel plants outside of MMI's supervision. Of the nearly 109 Mt of crude steel produced in 1997, 95\% came from enterprises in the MMI system, and almost $90 \%$ from MMI's key enterprises and major local enterprises.

Table 7. Crude Steel Production in China by Enterprise, 1997

\begin{tabular}{|c|c|c|c|c|}
\hline Enterprise & $\begin{array}{c}\text { Steelmaking } \\
\text { Process }\end{array}$ & $\begin{array}{c}\text { Year } \\
\text { Established }\end{array}$ & $\begin{array}{c}\text { Continuously } \\
\text { Cast Steel }(\%) \\
\end{array}$ & $\begin{array}{c}1997 \text { Crude Steel } \\
\text { Production (Mtonnes) }\end{array}$ \\
\hline Shougang Corp. & $\mathrm{BOF}$ & 1920 & 78 & 8.0 \\
\hline Tianjin Steel Plants & OHF & -- & 87 & 1.8 \\
\hline Tangshan Iron and Steel (Group) Co. & BOF & 1944 & 96 & 2.4 \\
\hline Xuanhua Iron and Steel Corp. & $\mathrm{BOF}$ & 1912 & 61 & 0.7 \\
\hline Taiyan Iron and Steel Co. & OHF, BOF, EAF & 1934 & 51 & 2.4 \\
\hline Baotou Iron and Steel Rare-earth Co. & OHF, BOF & 1954 & 29 & 0.4 \\
\hline Anshan Iron and Steel (Group) Co. & OHF, BOF & 1919 & 37 & 8.3 \\
\hline Benxi Iron and Steel Co. & BOF & 1910 & -- & 2.6 \\
\hline Fushun Steel Plant & EAF & 1938 & 20 & 0.4 \\
\hline Dalian Steel Plant & EAF & 1934 & -- & 0.3 \\
\hline Beigang Group Co. & EAF & 1957 & -- & 0.4 \\
\hline Shanghai Steel Plants: & OHF, BOF, EAF & & 70 & 6.6 \\
\hline Shanghai No. 1 I\&S Works & & 1943 & & \\
\hline Shanghai No. 3 I\&S Works & & 1918 & & \\
\hline Shanghai No. 5 I\&S Works & & 1958 & & \\
\hline Baoshan Iron and Steel Corp. & $\mathrm{BOF}$ & 1982 & 61 & 8.6 \\
\hline Shanghai Meishan (Group) 2 & N/A & 1970 & -- & 0.003 \\
\hline Maanshan Magang Steel Co. 3 & OHF, BOF & 1909 & 55 & 3.0 \\
\hline Wuyang Iron and Steel Co. & EAF & 1978 & 54 & 0.4 \\
\hline Wuhan Iron and Steel (Group) Co. & OHF, BOF & 1958 & 82 & 6.1 \\
\hline Yegang Group Co. & OHF, EAF & 1913 & 8 & 0.5 \\
\hline Panzhihua Iron and Steel (Group) Co. & BOF & 1970 & 41 & 2.9 \\
\hline Chongqing Iron and Steel (Group) Co. & $\mathrm{OHF}$ & 1940 & 99 & 1.2 \\
\hline Chongqing Special Steel (Group) Co. & EAF & 1937 & 6 & 0.1 \\
\hline Changcheng Special Steel Co. & EAF & 1965 & 11 & 0.4 \\
\hline Chengdu Seamless Steel Tube Plant & OHF & 1962 & 40 & 0.5 \\
\hline Guiyang Steel Plant & EAF & 1958 & -- & 0.2 \\
\hline Guizhou Steel Wire Rope Plant & EAF & 1966 & 50 & 0.03 \\
\hline Shuicheng Iron and Steel (Group) Co. & N/A & 1966 & 82 & 0.6 \\
\hline Shaanxi Steel Plant & EAF & 1965 & 10 & 0.2 \\
\hline Shaanxi Precision Alloy Co. Ltd. & EAF & 1965 & -- & 0.002 \\
\hline Juiquan Iron and Steel Co. & N/A & 1959 & 92 & 1.3 \\
\hline Xining Steel Plant & EAF & 1969 & -- & 0.4 \\
\hline Ningxia Shizuishan Iron and Steel Works & EAF & 1959 & -- & 0.08 \\
\hline Total/Average Key Enterprises & & 1951 (avg) & $57 \%$ & 67.67 \\
\hline Major Local Enterprises & & 1957 (avg) & $79 \%$ & 29.76 \\
\hline Small Enterprises & & & $\mathbf{5 9 \%}$ & 5.54 \\
\hline Other Producers & & & $59 \%$ & 5.94 \\
\hline Total Crude Steel Production & & & $61 \%$ & 108.91 \\
\hline
\end{tabular}

Source: Ministry of Metallurgical Industry, 1994; Ministry of Metallurgical Industry, 1998; Joint Study Team, 1994.

\footnotetext{
${ }^{3}$ Since the 1990 s, iron from non-MMI enterprises has risen rapidly, from a $4.8 \%$ share of national iron output in 1989 to $17 \%$ in
} 1997. The annual output of pig iron produced by non-MMI enterprises is now over 10 Mt (Energy Research Institute, 1999). 


\section{India}

The first steel plant in India began operation in 1912. In 1996, there were seven integrated iron and steel plants in India, using either the open hearth furnace or the basic oxygen furnace to produce crude steel (see Table 8). The integrated steel plants together produced $15 \mathrm{Mt}$ of crude steel, accounting for about $75 \%$ of India's steel production. Slightly more than $14 \%$ of total steel production in 1998 was through the open hearth furnace route (IISI, 1999). Some of the major sites have both basic oxygen furnace and open hearth furnace facilities. Only one of the seven integrated plants is privately owned (Tata Iron and Steel Company or TISCO), accounting for about $15 \%$ of total steel production in India (Schumacher and Sathaye, 1998). The other plants are owned by the Steel Authority of India Limited (SAIL) or Rahtriya Ispat Nigam, both public sector undertakings (Dalal, 1998). About half of the integrated plants have implemented continuous casting in part of their plants.

In addition to the integrated plants, India has about 180 secondary steel producers, using electric arc furnaces. In 1993/1994, however, only 93 of these furnaces were in operation (Singh et al., 1997). Electric arc furnaces in India are very small, with an average size of about $15 \mathrm{kt} / \mathrm{yr}$, compared to $150 \mathrm{kt} / \mathrm{yr}$ in the U.S. Part of the electric arc furnaces use scrap as input material, but also a substantial amount of direct reduced iron (or sponge iron) is used in electric arc furnaces (Singh et al., 1997). India is is one of the world's largest producers of DRI (Presny and Fafard, n.d.), predominately using natural gas. In 1993, India produced 2 Mt of DRI, accounting for $20 \%$ of total world production (Schumacher and Sathaye, 1998). By 1998, DRI production in India had increased to 5.12 Mt (IISI, 1999.). Another 500 smaller units rely on processes such as induction furnaces, melting by re-rollers and ship breaking units (Schumacher and Sathaye, 1998). Approximately 75\% of minimill (EAF) steel produced in India is continuously cast. In 1994, $22 \%$ of India's total steel production was processed using continuous casting; this ratio jumped to 50\% in 1998 (IISI, 1997; IISI, 1999; Schumacher and Sathaye, 1998).

Table 8. Crude Steel Production by Company/Plant in India, 1994

\begin{tabular}{|c|c|c|c|c|}
\hline Company/Plant & $\begin{array}{c}\text { Steelmaking } \\
\text { Process }\end{array}$ & $\begin{array}{c}\text { Year } \\
\text { Established }\end{array}$ & $\begin{array}{c}\text { Continuously } \\
\text { Cast Steel }\end{array}$ & $\begin{array}{c}1994 \text { Crude Steel } \\
\text { Production } \\
\text { (Mtonnes) }\end{array}$ \\
\hline \multirow[t]{2}{*}{ SAIL - Bhilai } & $\mathrm{OHF}$ & 1959 & yes & 2.4 \\
\hline & $\mathrm{BOF}$ & & yes & 1.6 \\
\hline \multirow[t]{3}{*}{ SAIL - Durgapur } & $\mathrm{OHF}$ & 1959 & yes & 0.3 \\
\hline & $\mathrm{TH}$ & & yes & 0.4 \\
\hline & $\mathrm{BOF}$ & & yes & 0.3 \\
\hline \multirow[t]{2}{*}{ SAIL - Rourkela } & $\mathrm{OHF}$ & 1959 & no & 0.2 \\
\hline & $\mathrm{BOF}$ & & no & 1.0 \\
\hline SAIL - Bokaro & $\mathrm{BOF}$ & 1972 & no & 3.7 \\
\hline SAIL - Bumpur (or IISCO) & $\mathrm{OHF}$ & 1922 & no & 0.3 \\
\hline Visakhapatnam Steel Plant (or Vizag) & $\mathrm{BOF}$ & 1989 & yes & 1.9 \\
\hline VISL Visvesvaraya Iron \& Steel Ltd. & $\mathrm{BOF}$ & -- & -- & -- \\
\hline \multirow[t]{2}{*}{ TISCO } & $\mathrm{OHF}$ & 1983 & yes & 1.2 \\
\hline & $\mathrm{BOF}$ & & yes & 1.6 \\
\hline Total Integrated Steel Production & & & & 14.9 \\
\hline ASP (SAIL) & EAF & & no & 0.2 \\
\hline VISL Visvesvaraya Iron \& Steel Ltd. & EAF & & yes & 0.08 \\
\hline Others & EAF & & & 4.6 \\
\hline Total Electric Steel Production & & & & 4.9 \\
\hline Total Induction Furnace Production & & & & $\mathbf{0 . 0 2}$ \\
\hline Total Crude Steel Production & & & $22 \%$ & 19.8 \\
\hline
\end{tabular}

Notes: TH = Twin open hearth furnace. SAIL statistics are for FY 94-95.

Sources: Chatterjee, 1996; Dalal, 1998; IISI, 1997; Steel Authority of India (SAIL), 1996. 


\section{Mexico}

The Mexican iron and steel industry started in 1903 with the construction of the first integrated plant of Fundidora de Monterrey (Fumosa). To satisfy the increasing demand of steel in the late 1940s, this plant was modernized and since then a number of new plants have been built. Some of the largest are: Altos Hornos de México (AHMSA); Hojalata y Lámina (HYLSA), which developed its own technology, HYL, to produce direct reduced iron; Tubos de Acero de México (TAMSA); and Siderúrgica Lázaro Cárdenas-Las Truchas (SICARTSA). HYLSA, TAMSA, and SICARTSA are all EAF plants using DRI, although the TAMSA plant closed recently (HYLSA, 1998). In addition to these large EAF plants, there are 14 companies operating 28 minimills using both scrap and DRI (see Table 9) (I\&SM, 1998). DRI production in Mexico uses natural gas, and, like India, accounts for $20 \%$ of the world total.

From the 1940s to the 1980s, the Mexican government supported the growth of the iron and steel industry with subsidies, financial incentives, and duty protection. In 1977, the government organized and managed AHMSA, Fumosa and SICARTSA as an associated group called Sidermex to optimize their productivity. Even so, the Fumosa plant closed in 1986 due to its low productivity and high costs. The privatization of the state-owned companies began in the late 1980s and was completed at the end of 1991. Since then, investment in expansion and modernization of iron and steel plants has grown and it was expected that such activities would continue until 2000 (Baro, 1997). In the privatization process, AHMSA was acquired by Grupo Acerero del Norte (GAN) and SICARTSA was acquired by Grupo Villacero. A new DRI plant, owned by HYLSA, commenced operation in April 1998 (I\&SM, 1998).

An industry trade journal reported the following regarding Mexico's current situation: "Mexican steel has shown an annual growth rate of $7.4 \%$ since the government privatized its steelmaking interests six years ago. Annual production climbed to 14.2 million metric tons last year from 6.9 million metric tons in 1991. Overall, imports have declined by $13 \%$. Mexico's trade balance in steel decreased from an accumulated deficit of U.S. $\$ 4.3$ billion from 1991 to 1994 to a surplus of $\$ 3.8$ billion from 1995 to 1997 . The most recent data provided by Mexico's steel council, Canacero, show that first quarter production for this year was 3.7 million metric tons, $7.5 \%$ higher than for the same 1997 period... Mexican steel output is expected to grow by nearly 7\% from last year. With capital expenditures in expansions and improvements of about $\$ 1$ billion this year, capacity should be $15 \%$ higher than last year, and production should reach 15.3 million metric tons." (I\&SM, 1998)

Table 9. Crude Steel Production in Mexico by Company/Plant, 1997

\begin{tabular}{l|c|c|c|c}
\hline Company/Plant & $\begin{array}{c}\text { Steelmaking } \\
\text { Process }\end{array}$ & $\begin{array}{c}\text { Year } \\
\text { Established }\end{array}$ & $\begin{array}{c}\text { Continuously } \\
\text { Cast Steel }\end{array}$ & $\begin{array}{c}\text { 1997 Crude Steel } \\
\text { Production } \\
\text { (Mtonnes) }\end{array}$ \\
\hline $\begin{array}{l}\text { Grupo Acerero de Norte (AHMSA) } \\
\text { Grupo Villacero (SICARTSA) } \\
\text { Total Integrated Steel Production }\end{array}$ & BF-BOF & 1944 & yes & 3.6 \\
\hline HYLSA & BF-BOF & 1976 & yes & 1.2 \\
Tubos de Acero de México (TAMSA) & DRI-EAF & 1944 & yes & \\
Industrias Monterrey (IMSA) & DRI-EAF & 1959 & yes & \\
Ispat Mexicana (IMEXA) & DRI & & yes & \\
Grupo Villacero (SICARTSA) & DRI-EAF & 1986 & yes & 3.3 \\
Minimills & DRI-EAF & & & \\
Total Secondary Steel Production & scrap-EAF & & & $\mathbf{8 . 8}$ \\
\hline Total Crude Steel Production & & & $\mathbf{8 3 \%}$ & $\mathbf{1 3 . 6}$ \\
\hline
\end{tabular}

Note: 1997 production value for integrated plants (4.8) differs from value in INEDIS database (5.1). 1997 production value for secondary steel from INEDIS database.

Source: ILAFA, 1991; I\&SM, 1991, 1993, 1994, 1996, 1998; Metal Bulletin Books, 1994; PEMEX, 1985. 


\section{E. South Africa}

Steel production in South Africa takes place through the blast furnace-BOF process, the Corex process, the EAF process, and as a co-product of vanadium production (ERI, 1994). In 1990, 52\% of South African crude steel was produced using the blast furnace-BOF process, $5 \%$ using the Corex process, $17 \%$ using direct reduced iron in EAFs, $12 \%$ using scrap in EAFs, and 14\% was a vanadium by-product (ERI, 1994; Worrell, 1998). South Africa is one of the two only countries in the world (besides South Korea) to produce steel using the Corex process. Another feature of the South African iron and steel industry is that it does not use pelletized ore, but uses lump ore (ERI, 1994).

ISCOR is the major steel company in South Africa, producing 76\% of the country's total crude steel in 1997 at its four plants (see Table 10). The first commercial COREX unit was constructed between 1985 and 1987 at ISCOR's Pretoria works, after first testing the process in Germany. The COREX process replaced an old (1934) blast furnace. South Africa possesses large reserves of suitable iron ores, but only small reserves of coking or metallurgical coals. However, coals suitable for smelt reduction are available in quantity (Hoffman, 1992), and the coal is available "on the doorstep" of the iron ore reserves. The smelting reduction process can use iron ores high in alkali content, as found in South Africa (Wintrell, 1992). Hence, the COREX process allowed the economic use of the local iron ore and coal reserves. The plant had various problems (due to inexperience) after the start-up in December 1987. After reconstruction and de-bugging, the plant has been successfully in operation since 1989 (Delport, 1991) and was given over to ISCOR. Reconstruction of some parts and new operation conditions improved the performance greatly, leading to production of high quality iron, and high productivity and availability (Delport, 1991). The plant demonstrated to be economically attractive (Delport, 1991), with 30\% lower production costs (Pühringer et al., 1991) than the blast furnace on site, despite the low capacity of the COREX unit. The clean excess fuel gas is used on site in furnaces and coke ovens (Pühringer et al., 1991). The COREX process proved to be very flexible (with respect to the fuel rate, and additives addition), insensitive to high alkali content of the ore (and burden), and easy to operate (Delport, 1991).

The preliminary success of the first COREX plant lead to the decision to build a larger COREX (C-2000, 650,000 tonnes per year) in South Africa by Saldanha Steel, a subsidiary of ISCOR. (In 1998, ISCOR decided to close the Corex-based Pretoria plant due to an "unprofitable economic situation"). The off-gases of the new COREX unit will be used to produce 800,000 tonnes per year of DRI, following a similar design to that at HANBO Steel, South Korea. This decision also seems to be based on the environmental performance of the COREX process, as the site is located near a nature preserve (VAI, 1996). This plant, which includes a thin slab caster, began operation in January 1999 (ISCOR, 1999; Saldanha Steel, 2001).

Table 10. Crude Steel Production in South Africa by Company/Plant, 1997

\begin{tabular}{l|c|c|c|c}
\hline Company/Plant & $\begin{array}{c}\text { Steelmaking } \\
\text { Process }\end{array}$ & $\begin{array}{c}\text { Year } \\
\text { Established }\end{array}$ & $\begin{array}{c}\text { Continuously } \\
\text { Cast Steel }\end{array}$ & $\begin{array}{c}\text { 1997 Crude Steel } \\
\text { Production } \\
\text { (Mtonnes) }\end{array}$ \\
\hline ISCOR - Vanderbijlspark & $\begin{array}{c}\text { DRI, BOF, } \\
\text { EAF }\end{array}$ & & Yes & 4.1 \\
ISCOR - Newcastle & BOF & & Yes & 1.7 \\
ISCOR - Vereeniging & EAF & & Yes & 0.4 \\
ISCOR - Pretoria & EAF & & Yes & 0.1 \\
Highveld Steel and Vanadium & BOF & 1960 & Yes & 0.8 \\
Scaw Metals & EAF & 1937 & Yes & 0.4 \\
Davsteel & EAF & 1974 & Yes & 0.2 \\
Other & & & & 0.5 \\
\hline Total Integrated Steel Production & & & & \\
Total Secondary Steel Production & & & $\mathbf{9 1 \%}$ & \\
\hline Total Crude Steel Production & & & $\mathbf{8 . 3}$
\end{tabular}

Note: The continuous casting share is for 1994.

Sources: ISCOR, 1999; Metal Bulletin Books, 1994. 


\section{International Comparison of Energy Use and Carbon Dioxide Emissions of the Steel Sector In Five Developing Countries}

\section{A. Historical Energy Use and Carbon Dioxide Emissions Trends}

\section{Primary Energy Consumption}

Total primary energy consumption in the iron and steel industry in the key developing countries is shown in Figure 14. China $\mathrm{g}$ consumes significantly more primary energy for steel production than the other countries due mostly to the much greater amount of steel produced. The steep rise in China from the early 1980s to the mid-1990s is especially remarkable, as is the slowing trend in the latest years for which there are data. Interestingly, primary energy consumption levels do not correlate exactly with steel production levels. Variations in primary energy use per tonne of steel produced are the result of trends in steel processes used, type of products produced, and the energy efficiency of steelmaking equipment.

Fuels used in iron and steel production include coal, natural gas, blast furnace gas, coke oven gas, residual and distillate fuel oil, biomass, and electricity. Figure 15 shows the 1995 shares of these fuels in the key countries. Coal is the dominant fuel used in all countries except Mexico, where $45 \%$ of total final energy use is provided by natural gas. Biomass provides $26 \%$ of the final energy used for steelmaking in Brazil. Figure 16 shows the share of electricity in total final energy consumption in the iron and steel industry, which is in the range of 5 to $15 \%$ for most countries.

Figure 14. Primary Energy Consumption for Steel Production

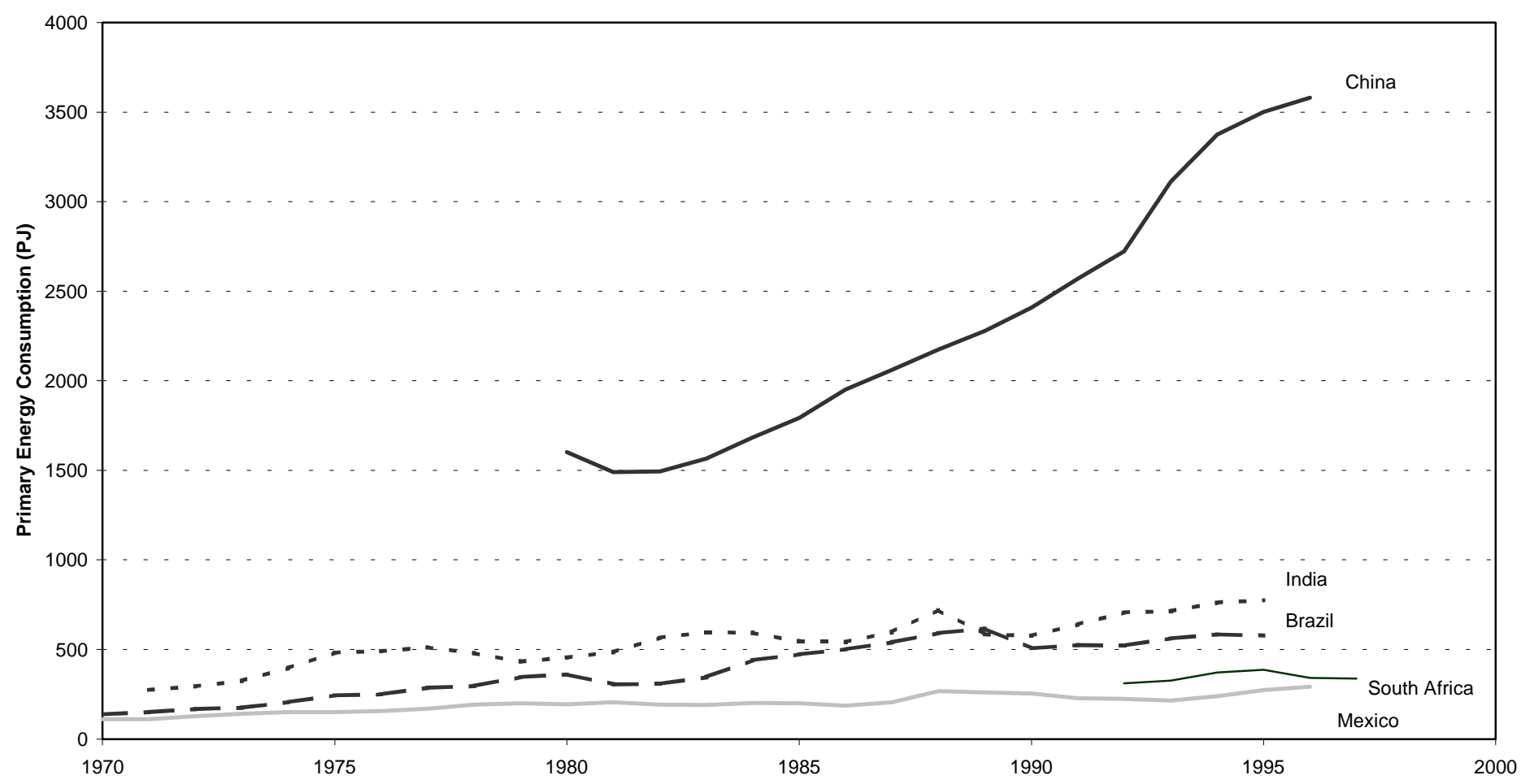

\footnotetext{
${ }^{4}$ Primary energy consumption is calculated by using a constant conversion efficiency of $33 \%$ in order to exclude differences in electricity generating efficiency between countries, thus highlighting only differences in energy efficiency in the production of steel.

${ }^{5}$ Energy use for steel production in China is based on values provided by the Energy Research Institute of the China State Development Planning Commission. Adjustments were made by LBNL based on information provided by ERI (ERI, 1999; Price et al., 2001).
} 
Figure 15. Fuels Used for Iron and Steel Production, 1995.

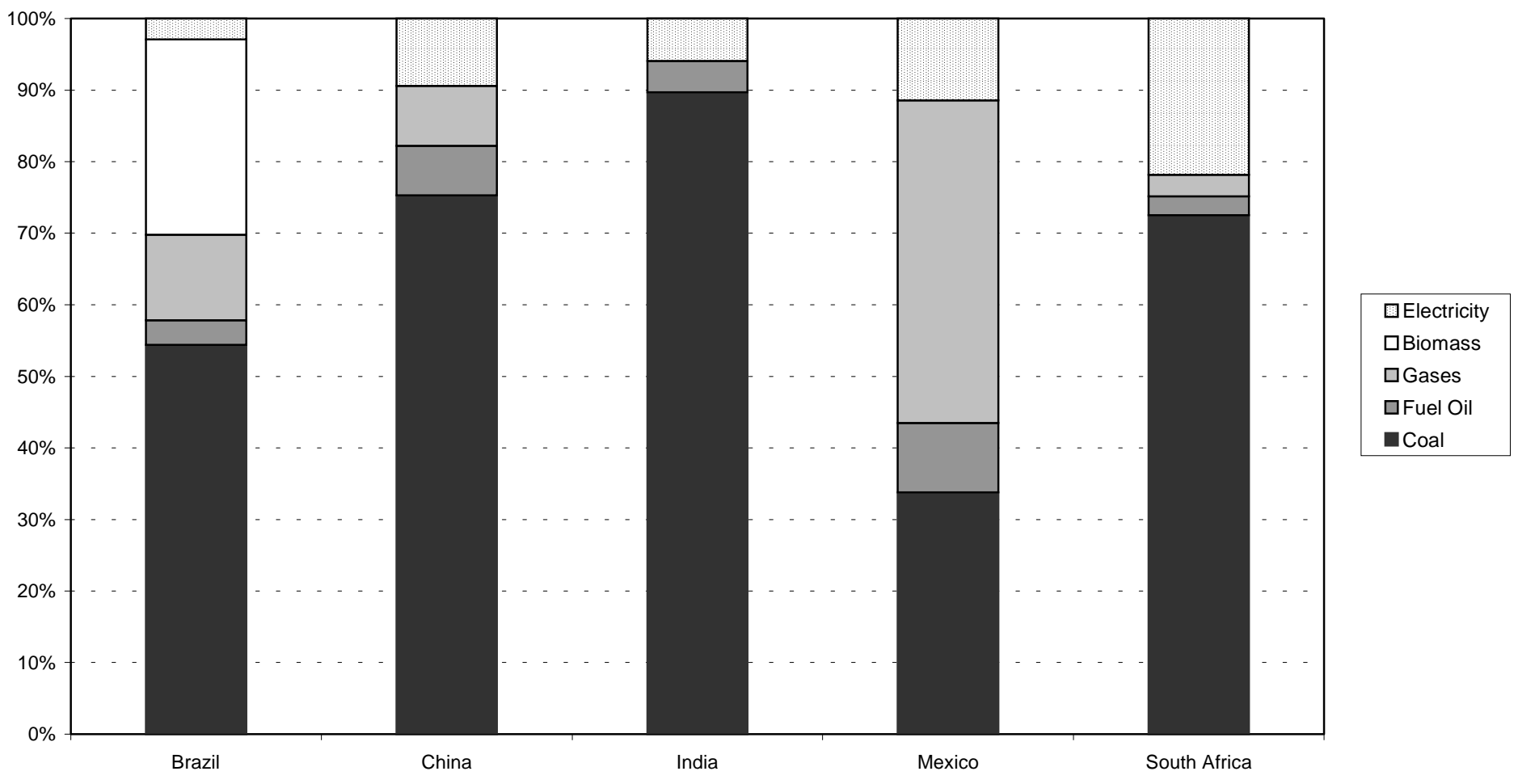

Figure 16. Share of Electricity in Final Energy Consumption

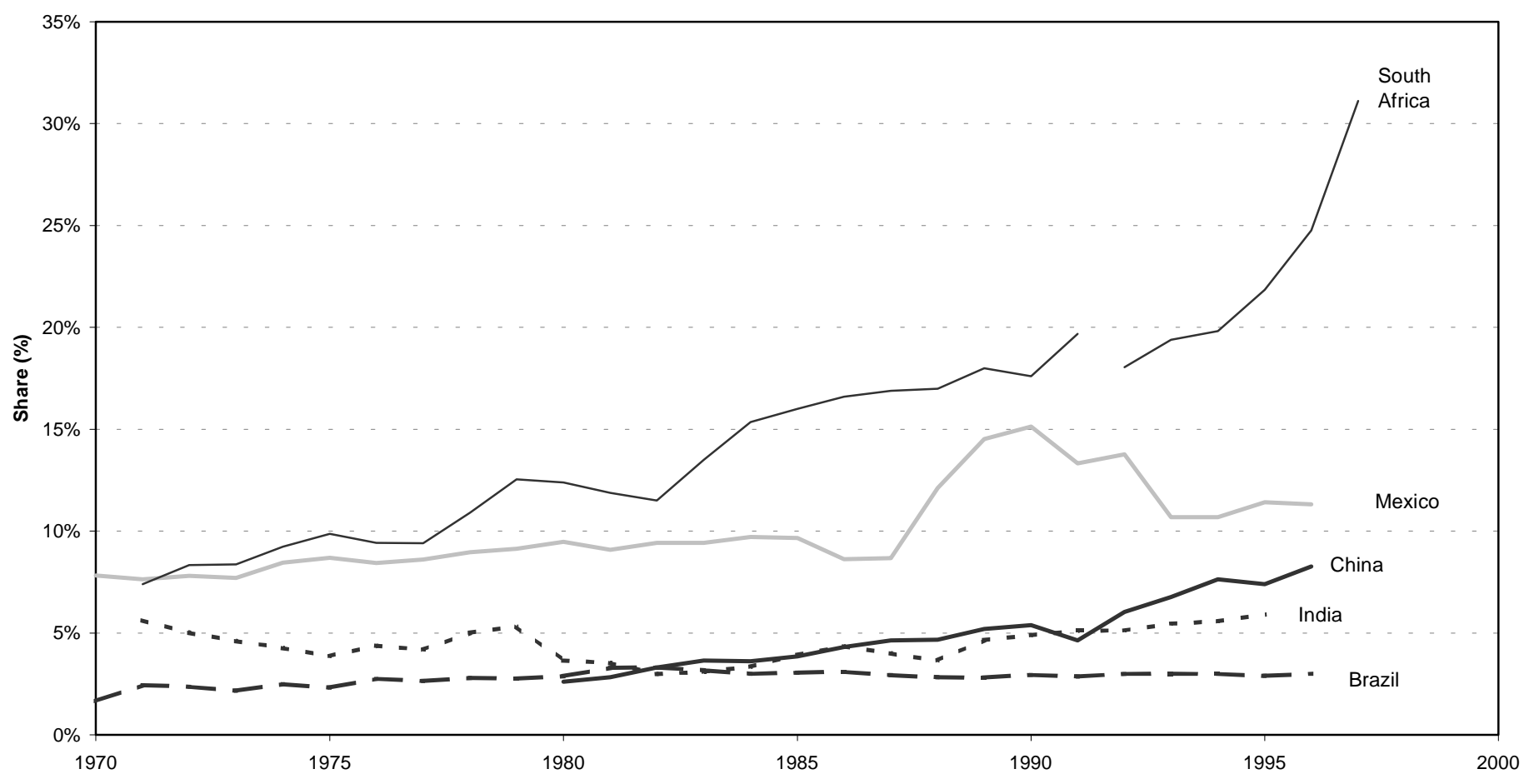




\section{Carbon Dioxide Emissions}

Carbon dioxide emissions from steel production for the key developing countries are shown in Figure 17. These emissions closely mirror primary energy use trends, with China clearly dominating followed by India, Brazil, and Mexico. Table 11 shows that carbon dioxide emissions from steel production are responsible for $13 \%$ of total emissions in Brazil, 12\% of total emissions in South Africa, 9\% of total emissions in China, $8 \%$ of total emissions in India, and 6\% of total emissions in Mexico (Maarland et al., 1999).

Table 11. Primary Energy Use and Carbon Dioxide Emissions in Five Key Developing Countries in 1995

\begin{tabular}{l|c|c|c}
\hline Country & $\begin{array}{c}\text { Primary } \\
\text { Energy Use } \\
(\mathbf{P J})\end{array}$ & $\begin{array}{c}\text { Carbon Dioxide } \\
\text { Emissions } \\
(\mathbf{M t C})\end{array}$ & $\begin{array}{c}\text { Share of Total Country } \\
\text { Carbon Dioxide } \\
\text { Emissions (\%) }\end{array}$ \\
\hline Brazil & 578 & 9.1 & $13 \%$ \\
China & 3502 & 82.7 & $9 \%$ \\
India & 775 & 20.4 & $8 \%$ \\
Mexico & 274 & 5.1 & $6 \%$ \\
South Africa & 389 & 9.6 & $12 \%$ \\
\hline
\end{tabular}

Note: total country emissions include process emissions.

Figure 17. Carbon Dioxide Emissions from Iron \& Steel Production

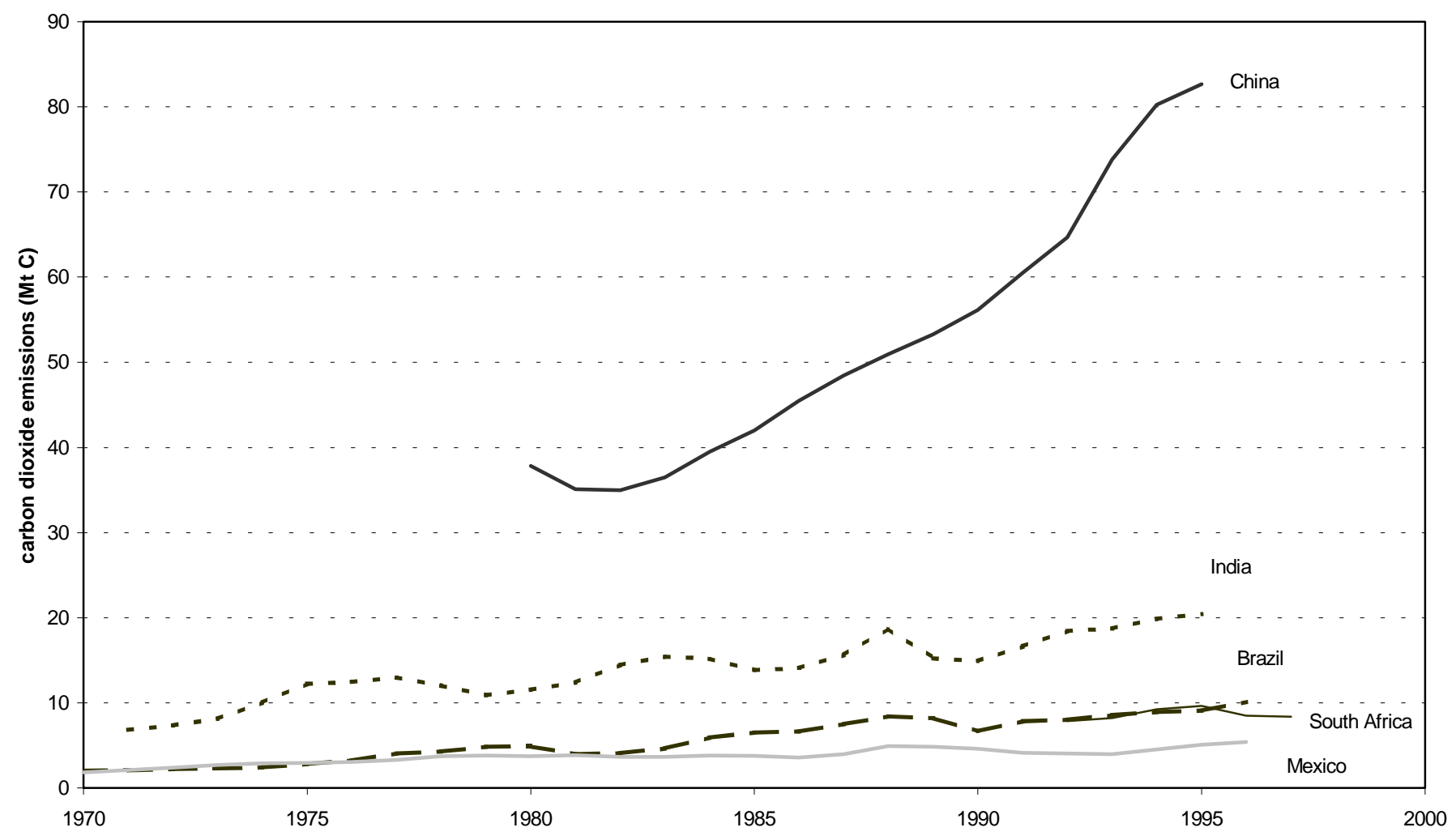




\section{B. Energy and Carbon Intensity Trends}

\section{Primary Physical Energy Intensity Trends}

Figure 18 shows primary physical energy intensity, measured as primary energy consumption per tonne of crude steel. ${ }^{-}$India and China have high primary energy intensity values. The downward trend in primary energy intensity has been relatively smooth in China, while India has experienced wide fluctuations. Brazil and Mexico have the lowest energy intensities of the five developing countries, but their intensity values are still higher than those found in many European countries, and some rapidly developing countries (e.g. South Korea).

\section{Energy Intensity Benchmarking}

The differences in primary physical energy intensities shown in Figure 18 are due to differences in energy efficiency as well as structural differences between countries. In order to account for the structural differences, we calculate a best-practice benchmark energy intensity using best-practice energy intensities for the actual product mix and feedstocks used in each country. The best-practice benchmark energy intensity is calculated to reflect the sector structure for each year for each country, based on that country's product mix and feedstock. In the iron and steel industry, product mix is defined as the share of iron, slabs, hot rolled steel, cold rolled steel and wire. Feedstocks (e.g., scrap, iron ore) are important because the product quality can be influenced by the scrap input due to contaminations from other metals (i.e., product mix is influenced) (Phylipsen et al., 1998).

These best-practice benchmark energy intensities are then compared to actual energy intensities. To make this comparison, we use an energy efficiency index (EEI), which is the ratio of the actual energy intensity to the best practice energy intensity, where the best practice equals 100. Figure 19 shows that steelmaking energy intensities in all of the countries decreased towards the best-practice benchmark value of 100 . By the mid-1990s, the steel industry in Brazil was the closest to best practice, followed by Mexico, China, and India, respectively.

Table 12 provides the 1995 actual and best-practice benchmark primary energy intensity values for Brazil, China, India, and Mexico, as well as the technical potential for primary energy savings, which is the difference between actual and best practice primary energy use. China and India have the highest technical potential for reducing primary energy use in steelmaking; 20 and $17 \mathrm{GJ} /$ tonne of steel produced in those countries, respectively, is made using outdated technology or inefficient practices. Potential savings in Mexico and Brazil are much lower.

Table 12. Best-Practice Benchmarking: Identification of Technical Potential Primary Energy Savings for Steelmaking in 1995

\begin{tabular}{l|c|c|c}
\hline Country & $\begin{array}{c}\text { Actual Primary } \\
\text { Energy Intensity } \\
\text { (GJ/tonne) }\end{array}$ & $\begin{array}{c}\text { Best-Practice Primary } \\
\text { Energy Intensity } \\
\text { (GJ/tonne) }\end{array}$ & $\begin{array}{c}\text { Technical Potential for } \\
\text { Primary Energy Savings } \\
\text { (GJ/tonne) }\end{array}$ \\
\hline Brazil & 23.1 & 18.6 & 4.5 \\
China & 36.7 & 20.2 & 16.5 \\
India & 37.3 & 20.5 & 16.8 \\
Mexico & 22.6 & 13.5 & 9.1 \\
South Africa & 44.4 & & \\
\hline
\end{tabular}

Note: For South Africa no best practice primary energy intensity can be calculated at this point, because no data are available on product mix.

\footnotetext{
${ }^{6}$ Primary physical energy intensity calculations were made based on the methodology developed by an international group of industrial energy analysts and outlined in Phylipsen et al., 1998.
} 
Figure 18. Primary Physical Energy Intensity

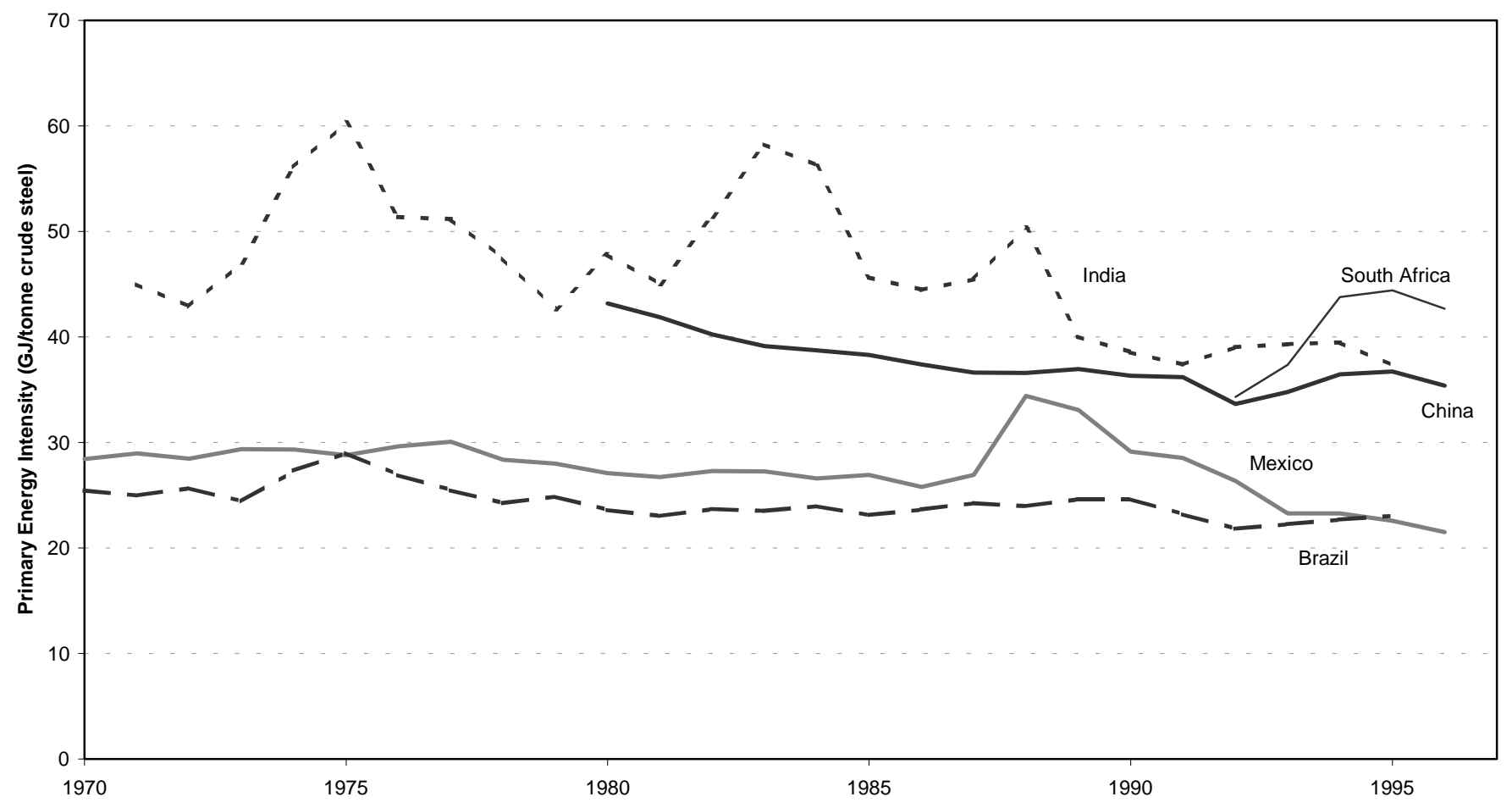

Figure 19. Best Practice Benchmarking for Steel Production

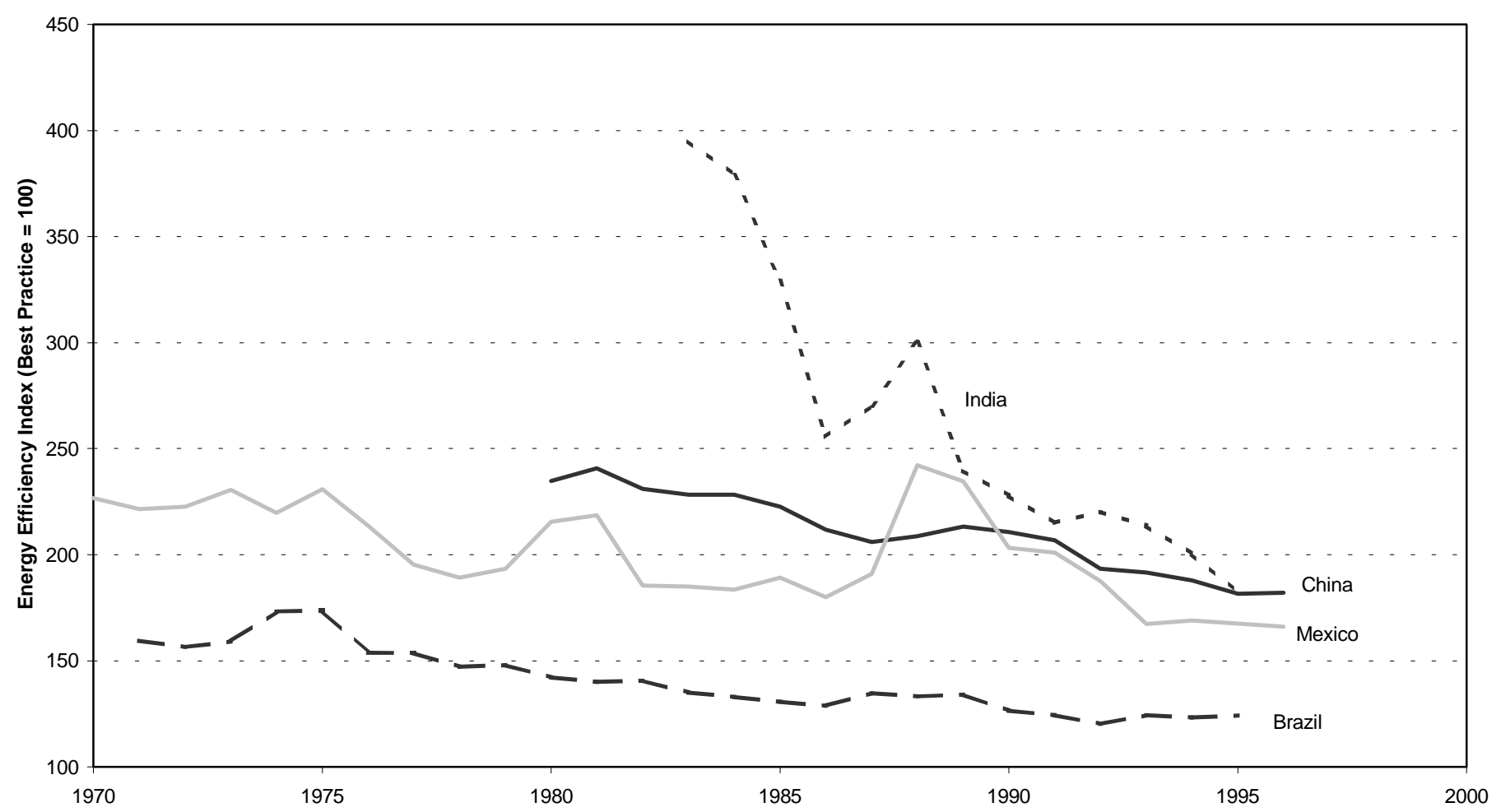




\section{Carbon Intensity Trends}

Carbon intensity trends are closely related to energy intensity trends but are also dependent upon the fuel mix used by the iron and steel industry in each country ${ }^{7}$ Figure 20 shows that South Africa, India and China have the highest carbon intensities from iron and steel production, while Brazil and Mexico have relatively low carbon intensities.

Figure 20. Carbon Intensity of Iron and Steel Production

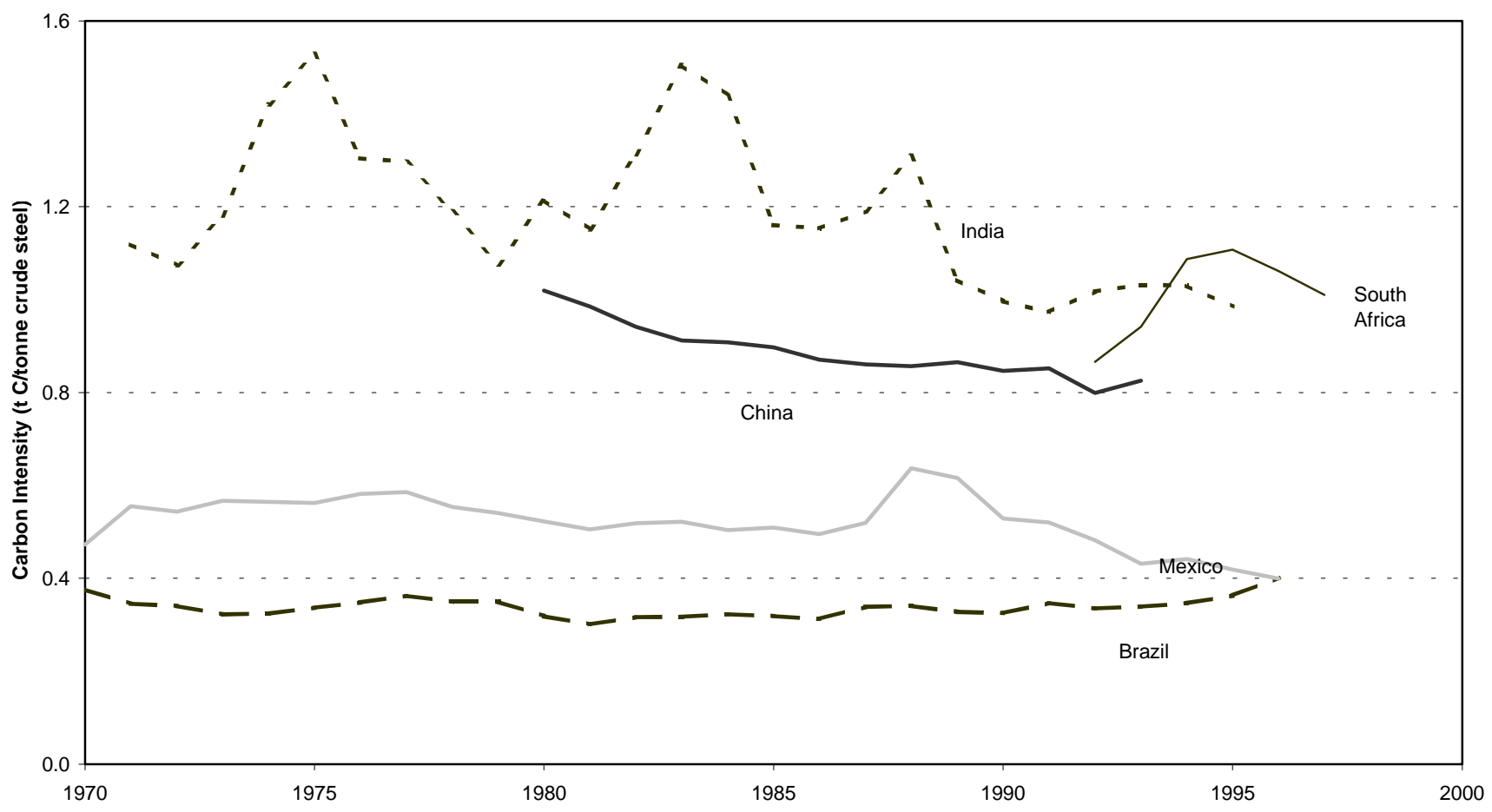

\section{Carbon Intensity Benchmarking}

As with energy intensity, the structural differences between countries can be taken into account by calculating a carbon-intensity index, which compares the actual level of emissions per tonne of product to a best-practice benchmark level of emissions. The best-practice benchmark carbon intensity for each of the processes and products is calculated by multiplying the actual carbon intensities by the best-practice carbon intensities and the carbon emission factor for each process. The sectoral best-practice benchmark carbon intensity is calculated as a weighted average based on the shares of the processes and products in each country. The carbon intensity index is the ratio of the actual carbon intensity to the best-practice benchmark carbon intensity, where a carbon intensity of 100 represents best practice, and the higher the carbon intensity index the higher the emission-reduction potential for a given sector structure.

Compared to the energy-efficiency index there is one complicating factor in calculating the carbon intensity index. In addition to sector structure and energy efficiency, fuel mix also influences $\mathrm{CO} 2$ emissions per tonne of product. Using the fuel mix associated with the best-practice technology in the carbon intensity index calculation implies a fuel switch from actual fuel mix to this best-practice fuel mix. Because of constraints on the availability of indigenous resources, this is not always economically feasible. Therefore, we have excluded the influence of fuel mix in our calculations of the carbon intensity index. This is done byusing a national-average fuel mix, instead of the best-practice fuel mix, to calculate the benchmark carbon intensity 8 . This means that the index is an indication of the emission-reduction potential by efficiency improvements only. Additional emissions reductions can be accomplished through fuel switching.

\footnotetext{
${ }^{7}$ Carbon emissions factors used in this analysis are from the Intergovernmental Panel on Climate Change (IPCC, 1996).
}

${ }^{8}$ This assumes that the efficiency of the best-practice technology does not change with changing fuel mix. 
Figure 21 presents the carbon-intensity index, showing the relationship between each country's actual carbon intensity and the best-practice benchmark carbon intensity each year. As with primary energy intensity, these countries have been moving closer to best practice over time, but large potentials still exist. As shown in Table 13, carbon dioxide emissions from steelmaking would be 0.4 to $0.5 \mathrm{tC}$ less per tonne of steel produced if best-practice technologies were used in China and India. Similarly, carbon dioxide emissions would be reduced 0.1 tC and 0.2 tC per tonne of steel in Brazil and Mexico, respectively, if those countries used best-practice technologies for steelmaking.

Table 13. Best-Practice Benchmarking: Identification of Technical Potential for Carbon Dioxide Emissions Reductions for Steelmaking in 1995

\begin{tabular}{l|c|c|c}
\hline Country & $\begin{array}{c}\text { Actual } \\
\text { Carbon Dioxide Intensity } \\
\text { (tC/tonne) }\end{array}$ & $\begin{array}{c}\text { Best Practice } \\
\text { Carbon Dioxide Intensity } \\
\text { (tC/tonne) }\end{array}$ & $\begin{array}{c}\text { Technical Potential for } \\
\text { Carbon Dioxide Savings } \\
\text { (tC/tonne) }\end{array}$ \\
\hline Brazil & 0.36 & 0.27 & 0.09 \\
China & 0.87 & 0.48 & 0.39 \\
India & 0.98 & 0.53 & 0.45 \\
Mexico & 0.42 & 0.24 & 0.18 \\
South Africa & 1.11 & & \\
\hline
\end{tabular}

Figure 21. Best Practice Carbon Intensity Benchmarking for Iron and Steel Production

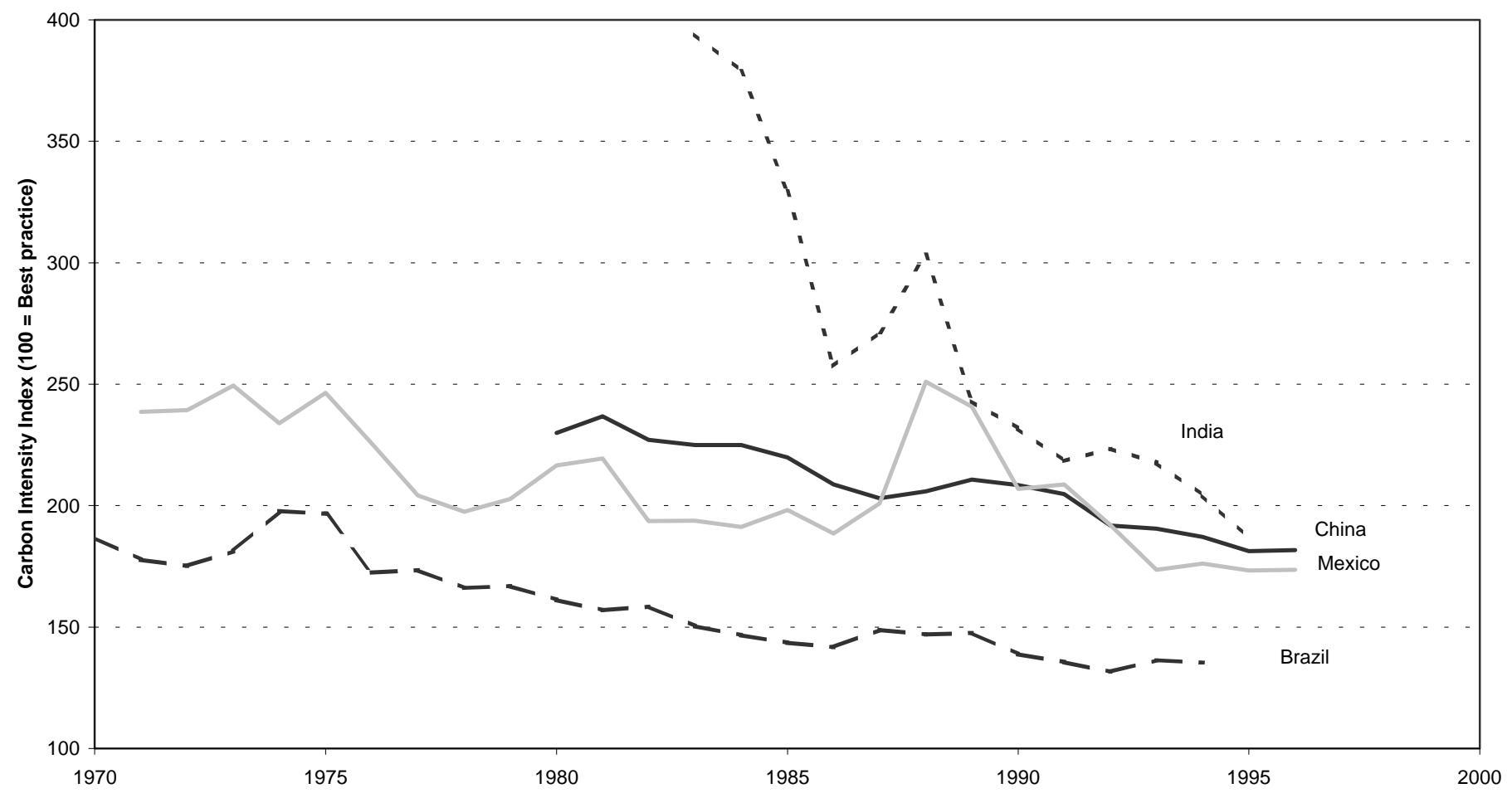




\section{Technical Potential for Primary Energy Savings and Carbon Dioxide Emissions Reduction}

If best practice technologies and practices were used by the key developing countries for production of steel, energy use and associated carbon dioxide emissions could be significantly reduced. Tables 14 and 15 provide the technical potential primary energy use savings and carbon dioxide emissions reductions for Brazil, China, Mexico, and India. If best practice technologies had been used in 1995 in China, India and Mexico, primary energy use and associated carbon dioxide emissions from steel production would have been 40-45\% lower than actual emissions. Carbon dioxide emissions would have been 26\% less in Brazil if best practices had been used in 1995. Except in the case of China, the potential for reduction in carbon emissions was slightly larger than the potential for reductions in energy use.

Identification of the technical potential for primary energy savings and carbon dioxide emissions reductions provides a rough estimate of the savings potential available in various countries. While the technical potential is based on actual energy use and carbon dioxide emissions from plants in commercial operation, country and plantspecific conditions will determine what portion of the technical potential can be realized in any given country.

Table 14. Summary of Technical Potential for Primary Energy Use Savings Using Best-Practice Technologies in 1995

\begin{tabular}{l|c|c|c|c}
\hline & $\begin{array}{c}\text { Annual } \\
\text { Steel } \\
\text { Production } \\
\text { (Mt) }\end{array}$ & $\begin{array}{c}\text { Actual } \\
\text { Primary Energy } \\
\text { Use } \\
\text { (PJ) }\end{array}$ & $\begin{array}{c}\text { Technical Potential } \\
\text { Primary Energy } \\
\text { Use } \\
(\mathbf{P J})\end{array}$ & $\begin{array}{c}\text { Difference } \\
\text { (Share of Actual } \\
\text { Primary Energy } \\
\text { Use) }\end{array}$ \\
\hline Brazil & 25.1 & 578 & 467 & $19 \%$ \\
China & 95.4 & 3502 & 1927 & $45 \%$ \\
India & 20.8 & 775 & 426 & $45 \%$ \\
Mexico & 12.1 & 274 & 163 & $40 \%$ \\
South Africa & 8.7 & 117 & & \\
\hline
\end{tabular}

Table 15. Summary of Technical Potential for Carbon Dioxide Emissions Reduction Using Best-Practice Technologies in 1995

\begin{tabular}{l|c|c|c|c}
\hline & $\begin{array}{c}\text { Annual } \\
\text { Steel } \\
\text { Production } \\
\text { (Mt) }\end{array}$ & $\begin{array}{c}\text { Actual } \\
\text { Carbon Dioxide } \\
\text { Emissions } \\
\text { (MtC) }\end{array}$ & $\begin{array}{c}\text { Technical Potential } \\
\text { Carbon Dioxide } \\
\text { Emissions } \\
\text { (MtC) }\end{array}$ & $\begin{array}{c}\text { Difference } \\
\text { (Share of Actual } \\
\text { Carbon Dioxide } \\
\text { Emissions ) }\end{array}$ \\
\hline Brazil & 25.1 & 9.1 & 6.8 & $26 \%$ \\
China & 95.4 & 82.7 & 45.8 & $45 \%$ \\
India & 20.8 & 20.4 & 11.0 & $46 \%$ \\
Mexico & 12.1 & 5.1 & 2.9 & $42 \%$ \\
South Africa & 8.7 & 8.6 & & \\
\hline
\end{tabular}




\section{Conclusions}

Production of iron and steel is responsible for 5 to $15 \%$ of total national carbon dioxide emissions in the five key steel-producing developing countries analyzed in this report (Brazil, China, India, Mexico, and South Africa). Production has been growing at extremely high annual rates, and such growth is likely to continue, based on recent trends and on the current low per capita production levels relative to industrialized countries.

Energy and carbon intensities of existing equipment in these countries are relatively high due to the use of inefficient technologies. The primary energy intensity of steel production in 1995 ranged from $22.6 \mathrm{GJ} / \mathrm{tonne}$ in Mexico to $37.3 \mathrm{GJ} /$ tonne in China and India. Using best-practice benchmarks tailored to each country, we found that significant savings, in the range of $33 \%$ to $49 \%$ of total primary energy used to produce steel, are technically possible in these countries. Similarly, we found that the technical potential for reducing carbon dioxide emissions intensities ranges between $26 \%$ and $49 \%$ of total carbon dioxide emissions from steel production in these countries.

A large number of technologies and measures exist for reducing energy use and associated carbon dioxide emissions from the iron and steel industry in these key developing countries. We found that India still used the inefficient OHF technology for $14 \%$ of its steel production in 1998 . We also found that while all of the countries had significantly increased their use of continuous casting, some countries (especially India) could still use more of this technology to improve energy efficiency. We identified a number of technologies that are appropriate for retrofits in existing plants. However, the largest opportunities most likely exist in the construction of new plants, where state-of-the-art technologies are significantly more energy-efficient than existing plants.

\section{Acknowledgements}

This work was supported by the Climate Protection Division, Office of Air and Radiation, U.S. Environmental Protection Agency through the U.S. Department of Energy under Contract No. DE-AC03-76SF00098.

We are deeply grateful to Li Ji and Hu Xiulian (Energy Research Institute, State Development Planning Commission of China) for providing extensive data and explanatory documents regarding production and energy use in the Chinese steel industry. We would also like to thank Leticia Ozawa Meida (Instituto de Ingenieria, Universidad Nacional Autonoma de Mexico) for data and information on the Mexican steel industry, Giovani Machado and Marcio de Costa (Federal University of Rio de Janiero) for data and information on the Brazilian steel industry, Katja Schumacher (International Energy Studies Group at Lawrence Berkeley National Laboratory) and Jan-Willem Bode (Department of Science, Technology and Society at Utrecht University) for data and information on the Indian steel industry, and Yvonne Blomkamp (Energy Research Institute, University of Cape Town), Chris Cooper (Rand Afrikaans University) and Johan van Wijk and Janneke Weidema (South African Department of Minerals and Energy) for their help on South African data. We would also like to thank Bryan Lehman (LBNL) for his on-going assistance with data collection and manipulation. Finally, we are grateful for the comments and suggestions provided by David Fridley (LBNL) and Jonathan Sinton (LBNL) on earlier versions of this report. 


\section{References}

Baro, E., 1997. “Mexico: Entre los Primeros 15 del Mundo,” Acero North American Steel Journal, 2 (3):18-20.

Brown, H. et al.. 1985. Energy Analysis of 108 Industrial Processes. Washington, DC: U.S. DOE.

Chatterjee, A., 1996. “The Steel Industry in India,” Ironmaking and Steelmaking, 23(4): 293-302.

Costa, M. and R. Schaeffer, 1997. "Energy and Materials Savings from Gases and Solid Waste Recovery in the Iron and Steel Industry in Brazil: An Industrial Ecology Approach," Proceedings of the 1997 ACEEE Summer Study on Energy Efficiency in Industry. Washington, DC: American Council for an Energy-Efficient Economy.

Dalal, 1998. Report on Potential for Improving Energy Efficiency and Environment in Integrated Steel Sector, Mumba, India: Dalal Consultants and Engineers Ltd, submitted to the Industrial Development Bank of India.

de Araújo, João Lizardo R. H., no date. Energy Use in the Brazilian Steel Industry: Prospects and Opportunities for Efficiency Improvement. Unpublished draft.

Delport, H.M.W., 1991. "The Corex Process," Proc. 2nd European Ironmaking Congress, Glasgow, UK, 15-18 September 1991.

Energetics, 1988. The U.S. Steel Industry: An Energy Perspective, Wahington D.C.: Energetics

Energetics, 2000. Energy and Environmental Profile of the U.S. Steel Industry. Prepared for the U.S. DOE, Office of Industrial Technologies. Washington, DC: Energetics.

Energy Research Institute (South Africa), 1994. The Potential Benefits of Improved Energy Effectiveness in Manufacturing and Mining in South Africa, Cape Town, South Africa: Energy Research Institute, University of Cape Town: ERI.

Energy Research Institute (China), 1999. Chinese Steel Input Data for INEDIS Database. Beijing: Energy Research Institute, State Development Planning Commission of China.

Hoffman, J.P., 1992. "Oxygen-Coal in Bath Smelting Reduction - A Future Process for the Production of Iron and Stainless Steel ?” J. S. Afr. Inst. Min. Metall. 92(8/9): 253-273.

HYLSA, 1998. "HYL Plants and Projects in Review," HYL Report, Spring, Vol. XII, no.1.

Instituto Brasileiro de Siderurgia (IBS), 1997. Anuário Estatistico: Brazil Steel Databook. Rio de Janeiro: IBS.

Instituto Latinoamericano del Fierro y el Acero (ILAFA), 1991. Repertorio Siderurgico Latinoamericano 1991. NY: ILAFA.

Intergovernmental Panel on Climate Change, 1996. Revised 1996 IPCC Guidelines for National Greenhouse Gas Inventories: Workbook. Geneva: IPCC.

International Iron and Steel Institute (IISI), various years. Steel Statistical Yearbook, Brussels: IISI.

International Iron and Steel Institute (IISI), 1990. Statistics on Energy in the Steel Industry (1990 Update). Brussel: IISI.

International Iron and Steel Institute (IISI), 1996a. Steel Statistical Yearbook 1995. Brussels: IISI. 
International Iron and Steel Institute (IISI), 1996b. Statistics on Energy in the Steel Industry (1996 Update). Brussel: IISI.

International Iron and Steel Institute (IISI), 1997. Steel Statistics of Developing Countries, 1996 edition, Brussels: IISI.

International Iron and Steel Institute (IISI) 1998a. Energy Use in the Steel Industry. Brussels: IISI.

International Iron and Steel Institute (IISI) 1998b. International Iron and Steel Institute Online, http://www.worldsteel.org/steeldatacentre/countries1998.htm. Brussels: IISI.

International Iron and Steel Institute (IISI), 1999. IISI web site:

http://www.worldsteel.org/steeldatacentre/lgcountry.htm Brussels: IISI.

I\&SM, 1991. "North American Basic Oxygen Furnace Round Up,” Iron and Steelmaking, 18 (8):6-7.

I\&SM, 1993. “Electric Arc Furnace Round Up,” Iron and Steelmaking, 20, May.

I\&SM, 1994. “Electric Arc Furnace Round Up,” Iron and Steelmaking, 21, May.

I\&SM, 1996. “Electric Arc Furnace Round Up,” Iron and Steelmaking, 23, May.

I\&SM, 1998. “Electric Arc Furnace Round Up,” Iron and Steelmaking, 25, May.

ISCOR, 1999. 1998 Annual Report, ISCOR website http://www.iscorltd.co.za/steel/, January 21, 1999.

Joint Study Team, 1994. China: Issues and Options in Greenhouse Gas Control. Washington, DC: The World Bank.

Kudrin, V., 1985. Steelmaking. Moscow: Mir Publishers.

Lawrence Berkeley National Laboratory, 1999. International Network on Energy Demand in the Industrial Sector (INEDIS) Database. Berkeley, CA: LBNL.

Li, S., and Wang, Z., 1999. "Present and Future Status of Chinese Steel Industry in the $21^{\text {st }}$ Century," Iron and Steel Engineer, August.

Maarland, G., R.J. Andres, T.A. Boden, C. Johnston, and A. Brenkert, 1999. Global, Regional, and National CO2 Emission Estimates from Fossil Fuel Burning, Cement Production, and Gas Flaring: 1751-1996. Oak Ridge, TN: Oak Ridge National Laboratory (http://cdiac.esd.ornl.gov/ndps/ndp030.html).

McAloon, T.P., 1994. “Alternate Ironmaking Update,” Iron \& Steelmaker 21(2): 37-39 + 55.

Metal Bulletin Books, 1994. Iron and Steel Works of The World, $11^{\text {th }}$ edition. London: Metal Bulletin Books.

Midrex, 1995. 1994 World Direct Reduction Statistics, Charlotte, NC: Midrex Direct Reduction Corporation.

Ministry of Metallurgical Industry, 1994. Yearbook of Iron and Steel Industry of China, Ministry of Metallurgical Industry, China.

Ministry of Metallurgical Industry, 1998. Yearbook of Iron and Steel Industry of China, Ministry of Metallurgical Industry, China.

Organization for Economic Co-operation and Development, 1995. World Steel Trade 1983-1993, Paris: OECD. 
PEMEX, 1985. Consumo de Energía en la Industria Siderúrgica, Perfiles Energéticos Industriales no. 2, Mexico City: PEMEX, Coordinación de Estudios Económico.

Phylipsen, G.J.M., K. Blok and E. Worrell, 1998. Handbook on International Comparisons of Energy Efficiency in the Manufacturing Industry, Utrecht, The Netherlands: Dept. of Science, Technology and Society, Utrecht University.

Presny, D., and C. Fafard, no date. Energy Savings Ideas in the Direct Reduced Iron Industry, Madison, WI: Resource Management Associates, Inc.

Price, L., L. Michaelis, E. Worrell., and M. Khrushch, 1998. "Sectoral Trends and Driving Forces of Global Energy Use and Greenhouse Gas Emissions: Focus on Buildings and Industry," Mitigation and Adaptation Strategies for Global Change 3:263-319. (See also LBNL Report 42817).

Price, L., J. Sinton, E. Worrell, D. Phylipsen, X. Hu, and J. Li, 2001. Energy Use and Carbon Dioxide Emissions from Steel Production in China. LBNL-47205, Berkeley, CA: Lawrence Berkeley National Laboratory.

Pühringer, O., H. Wiesinger, B.H.P. Havenga, R. Hauk, W.L. Kepplinger and F. Wallner, 1991. "Betriebserfahrungen mit dem COREX-Verfahren und dessen Entwicklungspotential," Stahl u. Eisen 111(9):37-44.

Saldanha Steel, 2001. "Milestones," http://www.ssteel.co.za/.

Schumacher, K., and J. Sathaye, 1998. India's Iron and Steel Industry: Evaluation of Productivity Growth through Economic, Statistical and Engineering Analysis. Berkeley, CA: LBNL.

Secretaria de Programacion y Presupuesto (SPP), 1980. La Industria Siderurgica en Mexico. Mexico, DF: SPP.

Singh, G., D. Presny and C. Fafard, 1997. Energy Efficiency Opportunities in Indian Mini-Steel and Rolling Mills. Madison, WI: Resource Management Associates.

Sinters and Pellets Magazine, 1999. Vol. 1.

Steel Authority of India (SAIL), 1996. Statistics for Iron \& Steel Industry in India, New Delhi: Steel Authority of India Ltd.

United Nations, 1996. World Population Prospects: 1996 Revisions, New York: UN.

Voest Alpine Industrieanlagenbau, 1996. COREX, Revolution in Ironmaking, Linz, Austria:VAI.

Wintrell, R., 1992. "Why Corex ?” Proc. 1992 Ironmaking Conference, New York: American Institute of Mining, Metallurgical, and Petroleum Engineers.

World Energy Council, 1995. Energy Efficiency Improvement Utilising High Technology, An Assessment of Energy Use in Industry and Buildings, World Energy Council, London, UK: WEC.

Worrell, E., J.G. de Beer and K. Blok, 1993, 'Energy Conservation in the Iron and Steel Industry', in: P.A. Pilavachi (ed), Energy Efficiency in Process Technology, Elsevier Applied Sciences, Amsterdam/London.

Worrell, E., 1995. "Advanced Technologies and Energy Efficiency in the Iron and Steel Industry in China," Energy for Sustainable Development, 2(4): 27-40. 
Worrell, E. and C. Moore, 1997. "Energy Efficiency and Advanced Technologies in the Iron and Steel Industry," in: Proceedings 1997 ACEEE Summer Study on Energy Efficiency in Industry, Washington, DC: ACEEE.

Worrell, E., 1998. "Energy Efficient Technologies in the Cement and Steel Industry - Experiences in Developing Countries," Workshop on Technology Transfer and Innovation in the Energy Sector, Amsterdam: Scientific and Technical Advisory Panel, Global Environmental Facility.

Worrell, E., N. Martin and L. Price., 1999. Energy Efficiency and Carbon Dioxide Emissions Reduction Opportunities in the U.S. Iron and Steel Sector, LBNL Report 41724. Berkeley, CA: Lawrence Berkeley National Laboratory 